\title{
Corporate stock and bond return correlations and dynamic adjustments of capital structure
}

\author{
This version: December 2014
}

\begin{abstract}
This paper analyses the effects of dynamic correlations between stock and bond returns issued by the same firm on the speed of adjustment towards target leverage. The results show that the estimated correlations are time varying, show persistence, and differ among firms. Analysis of the potential explanatory variables reveals that the correlations decrease with negative expectations about future aggregate risks, but only for firms with a low default probability. In contrast, correlations are positively associated with specific risk measures, especially idiosyncratic stock risk and financial leverage. The positive relation between the correlations and the leverage ratio suggests that target leverage can be achieved faster when the stock-bond correlation is high. Our results show that this is the case.
\end{abstract}

\section{JEL Classification: G32, G12, G14}

Keywords: Individual stock-bond correlation, leverage, idiosyncratic risk, economic cycles, speed of adjustment, target capital structure.

This article has been accepted for publication and undergone full peer review but has not been through the copyediting, typesetting, pagination and proofreading process, which may lead to differences between this version and the Version of Record. Please cite this article as doi: 10.1111/jbfa.12114. 


\section{Introduction}

Capital structure choices are one of the most important issues in corporate finance. From the trade-off theory perspective, firms optimally choose their capital structure to maximize the net benefits of debt. The benefits of debt come from tax savings (Modigliani and Miller, 1963) and the potential information that debt generates (Harris and Raviv, 1990; Stulz, 1990), while the costs include basically the expected losses of bankruptcy (Scott, 1976; Titman, 1984) and agency costs (Jensen and Meckling, 1976; Myers, 1977; Jensen, 1986). Empirical tests of the trade-off theory have consisted in evaluating cross-sectional relations between leverage ratios and firm characteristics which are used to proxy for both debt benefits and costs. Another way to test the implications of the trade-off theory is to examine whether firms actually have target leverage ratios or whether they rebalance their capital structure when they depart from their target.

Our paper contributes to this literature by showing that the firm's adjustment towards its target leverage ratio is faster when the correlation between the returns of stocks and bonds issued by the firm is higher. Of course, this empirical result can only be understood if we assume that i) the firm stock-bond correlation is not zero but, rather, time varying and differing across firms, ii) the stock-bond correlation is related to firm characteristics that are also relevant to capital structure decisions, and iii) changes in the market value of leverage are faster if both market debt and equity respond simultaneously to common sources of risk. Therefore, the goal of this paper is twofold. First, we estimate dynamic individual stock-bond correlations and analyse which variables can explain their variability both in time series and cross-sectionally. Second, we estimate a model for leverage adjustments towards the target in which the speed of adjustment is modelled as a function of the stock-bond correlation.

The correlation in stock and bond markets has been widely investigated at the aggregate level. ${ }^{1}$ However, research papers on the comovements between stocks and corporate bonds at the firm level are scarce. With the theoretical support of structural models that assume that equity and debt are contingent claims written on the same productive assets, some empirical studies analyze whether a variable related to one security is relevant in

\footnotetext{
${ }^{1}$ Although primary studies find a small but positive long-term correlation between stocks and Treasury bonds, the equity and bond markets have behaved very differently since the late 1990s, showing time-varying behaviour, with positive values in stable periods that decrease meaningfully during recessions (e.g. Gulko, 2002; Illmanen, 2003; Connolly, Stivers, and Sun, 2005; d'Addona and Kind, 2006; Baele, Bekaert, and Inghelbrecht, 2010).
} 
determining a characteristic about the other security. ${ }^{2}$ We also relay on structural models to justify a non-zero stock-bond correlation that varies in time and with firm value. For all firms in the Standard and Poor's (S\&P) 100 Index and with transaction bond prices available in the Trading Reporting and Compliance Engine (TRACE) database, we estimate dynamic correlations between individual stock and bond returns using three alternative methodologies: a rolling sample correlation, a dynamic conditional correlation (DCC) model such as Engle's (2002), and a corrected version of the DCC model that incorporates a non-synchronous trading adjustment that follows the initial proposal of Engle, Kane, and Noh (1996). Our results suggest that the correlations are, on average, small but very different, depending on the stock-bond pair, and are time varying, showing persistence.

Using panel data regression, we investigate the sources of variation behind the correlations dynamics in both the cross-sectional and time series dimensions, considering a large set of explanatory variables that includes cycle indicators, firm characteristics, or specific bond contract characteristics. On the one hand, structural models imply that equity and bond returns are related by ratio of equity elasticity to bond elasticity with respect to changes in firm value. This relation, which is positive on average, is composed of the ratio between equity and debt sensitivities to firm value and of the firm leverage ratio. Both these components vary with firm characteristics, especially those related to risk. Therefore, the final effect on the correlation is undetermined a priori. On the other hand, intertemporal asset pricing models recognise the importance of macroeconomic factors in explaining the prices of both securities. However, empirical results on relative response to changes in economic conditions are not available. Unique empirical insights come from the works of Campello, Cheng, and Zhang (2008), Elkamhi and Ericsson (2008), and Schaefer and Strebulaev (2008). All these papers assume Merton's (1974) model to show that equity-bond elasticity (equitybond return covariance) increases with the quasi-leverage ratio, firm volatility, and time to maturity. Our analysis of the potential determinants of the variability of stock-bond correlations indicate that the correlations do not respond to cycle indicators related to macroeconomic growth but, rather, diminish when negative expectations are measured with aggregate risk indicators, such as the volatility of consumption growth or the default spread.

\footnotetext{
${ }^{2}$ On the one hand, the effect of the volatility of equity on the bond price has been extensively analyzed (Campbell and Taskler, 2003; Cremers, Driessen, Maenhout, and Weinbaum, 2008; Zhang, Zhou, and Zhu, 2009). On the other hand, and in the opposite direction, the effect of bond rating changes on stock returns has also received great attention (e. g. Holthausen and Leftwich, 1986; Barron, Clare, and Thomas, 1997; AbadRomero and Robles, 2006).
} 
In addition, the correlation diminishes as the systematic stock risk (market beta) increases. Hence, bonds and stocks of the same firm become increasingly different the greater the uncertainty in the overall economy and the higher the stock's systematic risk. However, these associations are weaker or even disappear when the firm's default probability is high. In contrast, the correlation increases with the firm's specific risk. In particular, the stock-bond correlation is consistent and strongly associated with the firm's idiosyncratic stock risk and financial leverage.

The cross-sectional positive association between the leverage ratio and the stockbond correlation is consistent with the theoretical foundations of the structural models. Their positive time series relation can also be theoretically justified by models assuming agency costs. Models in line with that of Harris and Raviv (1990) or Stulz (1990) point out the benefits of debt in reducing information asymmetry, thus supporting a positive relation between leverage and firm value. Given that we are assuming that both market debt and equity respond in the same direction to changes in firm value and our empirical results support this assumption, the higher the correlation, the stronger the effect of firm value changes on the leverage ratio. Consequently, changes in capital structure towards the target leverage will be more effective for firms and periods showing high values in the stock-bond correlation. The final analysis in this paper involves the role of the correlation on the dynamic adjustment of capital structure. The literature on capital structure concurs on the dynamic rebalancing of leverage towards the target but differs about the speed of adjustment, which range from the slow adjustment of Fama and French (2002) to 35 percent annually for Flannery and Rangan (2006). The speed depends on the firm's access to capital markets, financial constraints, and macroeconomic conditions (e.g. Drobetz and Wanzenried, 2006; Drobetz, Pensa, and Wanzenried, 2007; Cook and Tang, 2010; Faulkender, Flannery, Hankins, and Smith, 2012). Our contribution relays on the use of the correlation as the variable informing about specific firm characteristics and market conditions. Then, we assume a leverage adjustment model in which the target leverage is defined by standard firm characteristics but the adjustment speed changes with the stock-bond correlation. Estimation of the model indicates that the speed of adjustment is positive and significantly related to the correlation. Therefore, when the market values of equity and debt react in the same direction after news of capital restructuration, the leverage objective can be achieved earlier.

The remainder of the paper is organized as follows. Section 2 theoretically justifies a non-zero correlation between bond and stock returns and point outs potential determinants of 
its variation. Section 3 describes the data. Section 4 explains the methodologies and the results for the dynamic estimation of the correlations. Section 5 analyses the determinants of stock-bond correlations. Section 6 studies the role of stock-bond correlations in revising deviations of firm leverage from the target capital structure. Section 7 presents our conclusions.

\section{Theoretical bases}

Structural (or dynamic) models are used for capital structure decisions and incorporate the idea of risky corporate debt. Starting with Merton's (1974), these models are based on the fact that the value of the equity and debt of the same firm can be written as functions of firm value. Therefore, these values (and thus their returns) must be correlated. More specifically, let $B$ be the market value of the debt of firm $j$ that promises to pay $D$ on date $T$ and let $S$ be the market value of the same firm's equity. Suppose that both values can be written as a function of the firm's value, $V$, at time $t$ :

$$
S_{j t}=f\left(V_{j t}, t\right) ; \quad B_{j t}=F\left(V_{j t}, t\right)
$$

Any change in firm value will affect both the equity and debt value as

$$
\frac{d S_{j t}}{d V_{j t}}=f_{V}\left(V_{j t}, t\right) \quad \text { and } \quad \frac{d B_{j t}}{d V_{j t}}=F_{V}\left(V_{j t}, t\right)
$$

where the subscripts in $f$ and $F$ denote partial derivatives.

We can transform the equations in (2) to obtain the return on equity, $R_{j t}^{S}$, and the return on debt, $R_{j t}^{B}$, respectively:

$$
\begin{gathered}
\frac{d S_{j t}}{S_{j t}}=\frac{f_{V}\left(V_{j t}, t\right) d V_{j t}}{S_{j t} V_{j t}} V_{j t} \leftrightarrow R_{j t}^{S}=\frac{f_{V}\left(V_{j t}, t\right)}{S_{j t}} R_{j t}^{V} V_{j t} \\
\frac{d B_{j t}}{B_{j t}}=\frac{F_{V}\left(V_{j t}, t\right) d V_{j t}}{B_{j t} V_{j t}} V_{j t} \leftrightarrow R_{j t}^{B}=\frac{F_{V}\left(V_{j t}, t\right)}{B_{i j}} R_{j t}^{V} V_{j t}
\end{gathered}
$$

where $R_{i t}^{V}$ represents the return on firm value. Combining (3) and (4), we obtain

$$
R_{j t}^{S}=\frac{f_{V}\left(V_{j t}, t\right)}{F_{V}\left(V_{j t}, t\right)} \frac{B_{j t}}{S_{j t}} R_{j t}^{B}
$$

which says that the equity and bond returns are related by the equity-bond elasticity with respect to changes in firm value, supporting the idea of non-zero correlations. The elasticity is 
composed of the ratio between equity and debt sensitivities to firm value and of the firm leverage ratio. Additionally, the elasticity is time varying and depends on firm characteristics.

The specific relation between stock and bond returns requires conditions that allow the specification of the functional form of the elasticity in (5). Under the simplest structural model, Merton's (1974), the assumption that firm value follows a diffusion process with constant instantaneous volatility and standard Brownian motion implies that the sensitivities ratio is

$$
\frac{f_{V}\left(V_{j t}, t\right)}{F_{V}\left(V_{j t}, t\right)}=\frac{f_{V}\left(V_{j t}, t\right)}{\left(1-f_{V}\left(V_{j t}, t\right)\right)}=\frac{\phi\left(x_{j t}\right)}{1-\phi\left(x_{j t}\right)}
$$

where $\phi$ is the cumulative standard normal distribution at $x_{\mathrm{j} t}=\left[\log \left(V_{j t} / D_{j}\right)+\left(r_{t}+\left(\sigma_{j}^{2} / 2\right)\right) \tau\right] / \sigma_{j} \sqrt{\tau}, r$ is the risk-free rate, $\sigma$ is the volatility of firm returns, and $\tau=T-t$ is the time until the maturity of the debt. Since the leverage ratio cannot be negative, this model predicts a positive correlation between bond and equity returns that depends on the variables that determine $\phi\left(x_{j t}\right)$. Empirically, Campello, Cheng, and Zhang (2008), Elkamhi and Ericsson (2008), and Schaefer and Strebulaev (2008) find that Merton's model implies equity-bond elasticity (equity-bond return covariance) increasing with the quasi-leverage ratio, firm volatility, and time to maturity.

Equation (5) also indicates that the elasticity is a function of the leverage ratio; leverage acts as a scale factor that produces a stronger relation between stock returns and bond returns for firms with higher leverage ratios. This is a logical prediction, given the assumptions of structural models; the higher the firm leverage, the riskier debt is and the stronger the covariability between debt and equity will be. Therefore, structural models predict a positive correlation, on average, that would increase with firm leverage ratio.

However, we additionally know that, first, both debt and equity values (the numerator and the denominator in the leverage ratio) depend on common factors that affect firm value. The final effect on the leverage ratio will depend on the relative importance of the numerator and of the denominator. Second, these common factors also affect bond and stock returns and, thus, their correlation. In this sense, there must be a serial relation between leverage and correlation of undetermined sign, a priori. Models that account for conflicts of interest between debtholders and equity holders can provide insights on this point. In particular, structural models with agency costs suggest that the use of debt reduces information 
asymmetry and would then have a positive effect on firm value; these models therefore predict that leverage can be positively related to firm value.

More specifically, models in the line with that of Harris and Raviv (1990) or Stulz (1990) show that the information that debt generates is useful for making the optimal decision about whether to liquidate or continue and thus firm value can be positively related to leverage. The model's aim is to identify the optimal level of debt to maximize firm value, taking into account the cost of default and the fact that an optimal liquidation decision will be made upon default. The firm value is given by

$$
\begin{gathered}
V(p)=\operatorname{Max}_{D \geq 0} \underbrace{P V(\text { Expected Income })}_{\text {Firm continuation }}+ \\
\underbrace{\int_{0}^{D} E(\max \{\text { Liquidation, Renegozation }\})-\text { Default Costs }}_{\text {Firm default }}
\end{gathered}
$$

where $p$ indicates prior beliefs about firm quality and $P V$ refers to present value. The first term represents the firm value in case of continuation, which is the present value of future expected incomes, and the second term is the expected gain in firm value given an optimal continuation policy that can be made thanks to the information that debt generates. The model makes the following predictions:

- The debt level, the market value of debt, and firm value increase with increases in liquidation value and decrease with increases in default costs.

- Leverage increases changes in capital structure due to either increases in liquidation value or decreases in default costs, are accompanied by increases in firm value.

Therefore, agency cost models have been used to justify empirically finding a positive relation between leverage and firm value. Since debt and equity values are both positively associated with firm value, a positive relation between the leverage ratio and stock-bond correlation would also be expected.

Summarising, the empirical implications suggested by these theoretical models are as follows: i) The stock-bond correlation will be not zero, will be time varying, and will depend on firm characteristics. ii) The stock-bond correlation will be higher for firms with higher leverage ratios. iii) The stock-bond correlation will be positively associated with leverage such that the correlation could be used to determine the target leverage. Therefore, the key 
contribution of the paper is the analysis of the role of the correlation in a firm's target leverage adjustment.

\section{Data}

\subsection{Stock-bond correlations}

For the estimation of dynamic correlations we employ daily stock and corporate bond returns issued by the firms on the S\&P 100. The sample period is from July 2002 to December 2009, which promises substantial time series variation since it includes the last part of an expansion cycle (2002-2006) and the recent and dramatic economic crisis (2007-2009).

TRACE database compiles information about all corporate bond transactions. It is a system by which all members must report any OTC corporate transaction in the secondary market following the rules approved by the Security and Exchange Commission in January 2001. ${ }^{3}$ The increase in the quantity and quality of the information provided by the TRACE system has been reflected in the increasing number of research papers studying market transparency and liquidity. ${ }^{4}$ We collect all transactions regarding bonds issued by the firms on the S\&P 100 and, after applying the filters proposed by Dick-Nielsen (2009) to eliminate erroneous reports, we save the daily close prices. ${ }^{5}$ Next, some filters reduce the final number of bonds in our sample. First, we only use bonds with fixed coupon rates, non-callable, nonputable, non-sinking funds, and non-convertible bonds to avoid simultaneity effects on their prices. Second, we eliminate bonds that do not fulfill both the criteria of having at least three years of data available and 10 liquidity observations per month. ${ }^{6}$ This results in a final sample of 467 bond issues of 72 firms.

\section{[Table 1]}

Table 1 provides descriptive statistics comparing our selected bonds to the whole population in TRACE database. The first panel shows the distribution of issuers and issues by industry. In both cases the most representative industry for bond issuers is the industrial

\footnotetext{
${ }^{3}$ The actual reporting started in July 2002, with the dissemination of all trades in bonds with an initial issuance above $\$ 1$ billion and in the 50 highest-yield bonds and was completed in October 2004, with 99 percent of all trades reported in real time.

4 Edwards, Harris, and Piwoward (2007), Bessembinder, Maxwell, and Venkaraman (2006), Goldstein, Hotchkiss, and Sirri (2007) or Dick-Nielsen, Feldhütter, and Lando (2012) are examples.

${ }^{5}$ We would like to thank Jens Dick-Nielsen for his help in answering all our doubts about the implementation of the filters.

${ }^{6}$ If the latter condition is not reached, we relax this constraint to observe at least 30 observations in the quarter in which the month belongs.
} 
group; 76 percent of issuers in our sample and 65 percent in TRACE belong to this group. Regarding bond issues, as expected, 67 percent of all bonds in TRACE are issued by financial firms. In our sample, bonds belonging to industrial and financial firms represent similar percentages of the whole sample (54 percent and 43 percent, respectively). In any case, the second panel in Table 1 shows that there are no major differences in yield, coupon, maturity, and Treasury Spread, on average, between our selected sample and the whole database, although standard deviations are generally larger in TRACE, given that the variety of issues is higher. Finally, the number of issues per issuer is slightly lower in our sample (six, compared to eight for the whole database), but in both cases the number of issues per firm is higher in the financial sector.

The daily close prices for the stocks of the firms on the S\&P 100 are similarly collected from the Center for Research in Security Prices (CRSP). Daily returns obtained from the daily prices of stock and bonds are used to estimate a series of dynamic correlation for each stock-bond return pair. Therefore, 467 correlations are estimated and analysed.

\subsection{Determinants of correlations}

We analyse the cross-sectional and time series variations of the correlations with panel data regression analysis, including macro variables, firm-specific variables, and bond-specific variables as potential determinants. Here we describe the variables. Details on the data sources, computations, and estimation methodologies for constructing these variables and their descriptive statistics are in the Appendix.

In the group of macroeconomic or state variables, we consider different cycle indicators based on both the financial and real sides of the economy. Specifically, we use four variables indicating economic growth: the gross domestic product (GDP) growth rate $(\Delta \mathrm{GDP})$, the industrial production index (IPI) growth rate ( $\Delta \mathrm{IPI})$, the aggregate consumption growth rate $(\Delta c)$, and a dummy for crisis (NBER). We employ a group of variables related to uncertainty in both the real and financial markets that are expected to anticipate recessions: the volatility of the aggregate consumption growth rate $\left(\sigma_{c}\right)$, the volatility of market return $\left(\sigma_{\mathrm{SP}}\right)$, the implied volatility computed from prices of options written on the S\&P index (VIX), and a default spread (Default). We also include the term structure of interest rates (Term) as an indicator of future good conditions. The short-term interest rate (TBill) is considered since both the theoretical model and the empirical evidence provided by Campello, Cheng, and 
Zhang (2008) indicate that increases in the risk-free rate can produce decreases in the correlation between the two assets.

As we argued before, the value of the firm, which is indirectly related to its risk, is a common determinant of firm bond and stock returns. To approximate the firm's equity risk, we consider total risk $\left(\sigma^{\text {Tot }}\right)$, systematic risk $(\beta)$, and idiosyncratic risk $\left(\sigma^{\mathrm{Id}}\right)$. The group of variables representing the financial component of firm risk includes the leverage ratio (Lev) and the default probability (Default Prob). As measures of firm operational risk we use industry dummy variables (Ind1 and Ind2) and the unlevered beta $\left(\beta^{\mathrm{UN}}\right)$. Since Jensen and Meckling (1976) and Myers (1977), we know that incentive conflicts between equity and debt holders increase the firm's cost of debt. A partial solution to this problem is to restrict the actions of the firm's equity holders by adding debt covenants. We also use a covenant indicator (Cov) as a proxy of financial risk for each bond.

To control for bond characteristics regarding the interest rate risk, we use the coupon level (coupon) and the time to maturity (time). Finally, given the importance of illiquidity risk in both the stock and bond returns, we consider the measure of illiquidity proposed by Amihud (2002) for both assets in each pair. ${ }^{7}$

\subsection{Determinants of target leverage}

In the final empirical analysis, we estimate a model for the firm's adjustment towards the target capital structure that involves approximation of the target leverage ratio. For this we employ standard firm characteristics considered in the previous literature. Hovakimian, Opler, and Titman (2001), Fama and French (2002), Korajczyk and Levy (2003), Kayhan and Titman (2007), and Flannery and Rangan (2006) find that firms with higher earnings, growth opportunities, and intangible assets have lower leverage target ratios, while larger firms have higher ratios. Then, as firm characteristics, we include the logarithm of total assets (Size), earnings before interest and taxes over total assets (ROA), the market-to-book ratio (MTB), computed as the market value of equity plus the book long-term debt over total assets, and intangible assets over total assets (Intang). In addition, we consider the effective tax rate $(\mathrm{TAX}),{ }^{8}$ as the main advantage of levered firms and the interest coverage ratio (IC), which is the ratio between interest paid and earnings before interest and taxes, as a proxy for financial

\footnotetext{
${ }^{7}$ The main advantage of Amihud's illiquidity ratio is that it can be easily computed using daily data during long periods of time.

${ }^{8}$ The marginal tax rates correspond to the non-parametric marginal tax rates developed by Blouin, Core and Guay (2010).
} 
distress. Finally, we include the average leverage ratio within all firms in the industry (LevInd) to control for other firm characteristics. All variables are computed using quarterly data from COMPUSTAT.

\section{Stock-bond correlation estimation}

Studies about which model provides the best estimate for the correlation between aggregate stock and bond returns are abundant, whereas that is not the case for individual corporate stock-bond comovements. Therefore, instead of assuming a determined model for the correlations, we estimate the correlations with purely data-driven methods. The most employed dynamic estimation methods are versions of multivariate generalized autoregressive conditional heteroskedasticity $(\mathrm{GARCH})$ models. The DCC model of Engle (2002) has the property that decomposes the covariance matrix into volatilities and correlations. Then, the estimation can be done in two steps: in the first step, the volatility of each asset is estimated and, in the second step, the estimation of the dynamic correlation is obtained from the dynamic covariance of the standardized returns.

One important problem with individual bond prices of daily frequency is series discontinuities because of the lack of transactions on some days. Consequently, some bond returns are generated during more than one day. This non-synchronicity problem between bond and stock returns can bias the estimation of the correlation between them. We treat this problem in two ways. The first approach consists of homogenizing the bond and the stock price series by eliminating in both of them the days without prices in the bond sample. Then the returns are computed as if the prices were consecutive, but adjusting them by dividing by the number of days between prices:

$$
R_{t}=\frac{1}{h}\left[\log \left(\frac{p_{t}}{p_{t-h}}\right)\right]
$$

where $R$ denotes return, $p$ is the asset price and, $h$ represents the number of days without prices. The second approach admits and incorporates the fact that sometimes the information disclosure process takes more than one day. We compute standard bond and stock log returns,

$\log \left(\frac{p_{t}}{p_{t-h}}\right)$, for all days with prices in the bond sample. We follow and extend the proposal of Engle, Kane, and Noh (1996), originally developed for the gaps during weekends in GARCH-type models, for the case of any $h$-day gaps between prices in the estimation of both the individual conditional variances $\left(\sigma_{t}^{2}\right)$ and the conditional stock-bond correlation $\left(q_{S B, t}\right)$ : 


$$
\begin{gathered}
\sigma_{t}^{2}=h_{t}^{\delta}\left(h_{t-h}^{-\delta}\left((1-\alpha-\beta) \sigma^{2}+\alpha R_{t-h}^{2}+\beta \sigma_{t-h}^{2}\right)\right), \\
q_{S B, t}=h_{t}^{\delta}\left(\rho_{S B}+h_{t-h}^{-\delta}\left(\alpha\left(z_{S, t-h} Z_{B, t-h}-\rho_{S B}\right)+\beta\left(q_{S B, t-h}-\rho_{S B}\right)\right)\right),
\end{gathered}
$$

where $z$ are standardized returns, divided by their conditional standard deviation. This specification captures how the variances and the correlation can slow down or speed up when gaps due to non-trading days occur, where $\delta$ is the speed parameter. If prices are consecutive, $h=1$, the model is the standard DCC. When $h>1$, the effect of the non-trading problem will depend on the relation between $h_{t}$ and $h_{t-h}$ and on the value of $\delta$. We call correlations estimated using this adjusted DCC-GARCH procedure DCCD correlations.

Daily series of stock-bond correlations are estimated using the DCC and DCCD models by the quasi maximum likelihood method. For brevity, we do not report the estimations of the parameters for the 467 correlations. Instead we discuss the most relevant patterns. The estimated values for the parameter associated with the short-term shocks are concentrated in the whereabouts of zero in both the DCC and DCCD estimations (the median values are 0.012 and 0.014 , respectively), but the DCCD model produces higher dispersion. The persistence parameter indicate that the correlation is relatively persistent (the median values for the DCC and DCCD estimates are 0.679 and 0.5696), although there are cases with $\beta<0$. Finally, regarding the parameter for the power of the number of days without a price in the DCCD specification, its estimated value is lower than one, in absolute value, for 344 out of 467 stock-bond pair returns. This indicates that, generally, the non-trading adjustment will reduce the effect of both the shock and the persistence terms in the forecast of the next period correlation. However, it is also true that $\delta$ takes on very high values in some cases. We return to this fact later.

From daily correlations obtained by the DCC and DCCD models, we compute the average correlation within each month for having monthly series, since it is the available frequency of the explanatory variables that we employ in the next analysis. Additionally, we compute monthly sample correlations by using a rolling and overlapped window of three months of daily returns, as do Andersson, Krylova, and Vähämaa (2008) and Demiralp and Hein (2010).

It must be noted that we are not interested in finding the best method for estimating dynamic correlations between stock and bond returns. We employ three different methods to check the robustness of the conclusions about what variables are related to the cross-sectional 
and time series behaviours of these correlations. However, it can be interesting some comparison between the three estimates. We compare the three estimates in cross-sectional terms by analysing the distribution of the first, second, and third quartiles of the 467 correlations in Table 2. After that, differences in the time series dynamics of the three estimates are commented on throughout select representative cases displayed in Figures 1 and 2.

\section{[Table 2]}

Looking at the median value of the 467 correlations, we find the three estimation methods to be very similar. Density is concentrated around zero but the dispersion range is wide, as indicated by the minimum, the maximum, and the standard deviation. Moreover, the high values for kurtosis indicate that the distribution of median values has thicker tails than the normal distribution, mainly in the DCCD case. Sample correlations are much more volatile than the two estimated correlations based on GARCH specifications, as shown by the range of dispersion in the mean and median between the quartiles. However, the negative skewness and excess kurtosis of the first quartile in the case of DCCD denote that this method produces more extreme negative values for the correlation. Finally, the last panel in Table 2 reports information about the first autocorrelation of the monthly series. The two DCC methods produce monthly correlations with similar levels of persistence (approximately 0.2) while the sample correlation estimation produces series that are much more persistent because of the overlapping procedure employed in this case.

\section{[Figure 1]}

Figure 1 shows two examples of the time pattern of the sample and DCC estimated correlations. The graphs indicate the name of the firm issuer and the identification number of the specific bond issue in the stock-bond pair. The selection of these two examples obeys representative criteria: they involve firms in the two most representative industries in our sample (manufacturing and financial industry), the selected bonds show transaction prices in most of the days in our sample period, and are alive during the crisis period. Sample and DCC estimations show the same long-run mean. Therefore, differences between the variables that determine the cross section of the correlations between the two estimation methods in the next section are not expected. The long-run mean of correlation is low in both graphs but, while it is around 0.1 for the financial firm, both the sample and DCC correlations are negative in most months in the case of the manufacturing firm. Regarding temporal 
dynamics, the sample and DCC estimates show increases and decreases at similar times, but the sample estimation is much more volatile. Based only on the visual representation provided by Figure 1, it seems that the correlations are not related to economic moments.

[Figure 2]

Figure 2 compares standard DCC and adjusted DCC estimations for non-trading days. In this case, the selection of the correlations displayed is based on the differential elements between the two methods: the number of days without a price between two consecutive observed prices $(h)$ and its power parameter $(\delta)$. The top graph displays the correlation for the bond with the minimum gap between prices at the mean: 1.45 days. ${ }^{9}$ As expected, DCC and DCCD correlations are very close to each other. In contrast, the central graph displays the correlations regarding the bond with the maximum gap between prices at the mean: 2.89 days. In this case, DCC and DCCD are more different in months in which the number of days without a price is especially high. ${ }^{10}$ There are 43 correlations for which the DCCD estimation produces very high values for $\delta$, in the range between 32 and 53 approximately. However, such high values produce economically reasonable dynamic correlations. The bottom graph in Figure 2 represents the DCC and DCCD estimates for the most extreme case: $\delta=53.04$. The high value for the power parameter upwardly adjusts the standard DCC during practically all the months, independent of the values of $h$. However, the dynamics of the two estimated correlations follow the same temporal pattern and the magnitude of the adjustment is moderated.

\section{The determinants of the correlations}

\subsection{Panel estimation}

The aim of this Section is to analyse the variation of stock-bond return correlation on both a time series and cross-sectional basis by regression analysis using panel data estimation techniques. To be consistent with the estimation of the dynamic correlations, we admit potential persistence in the dependent variable and run the regression

$$
q_{i t}=\alpha q_{i t-1}+x_{i t}^{\prime} \beta+\varepsilon_{i t}
$$

\footnotetext{
${ }^{9}$ The mean gap between prices is higher than one in all cases because we include weekends.

${ }^{10}$ The difference between the two correlations is remarkable in November 2005, where the bond shows 13 consecutive days without trades.
} 
where $q_{i t}$ is the correlation for the stock-bond return pair $i$ and month $t$ and $x_{i t}$ is the vector of exogenous variables in which we include all the variables indicated in the data Section. ${ }^{11}$ To deal with the potential fixed effects in the error term, equation (10) is differentiated and estimated by the system generalized method of moments (GMM), initially proposed by Arellano and Bover (1995) and later developed by Blundell and Bond (1998). The system GMM has the advantage of also exploiting the information contained in the data in levels by including a new set of moment conditions regarding the untransformed data (levels) while retaining the original conditions for the transformed (differenced) equation. In addition, this methodology allows including time-invariant regressors in the model. The bias in the standard errors are controlled by using the correction proposed by Windmeijer (2005), which produces robust GMM estimators. Regarding the instruments, after some empirical estimations comparing the performance of the models, we decided to employ lags of the dependent variable to instrument the system GMM and to consider all explanatory variables as strictly exogenous. We use the residuals autocorrelation test of Arellano and Bond (1991) for selecting the number of lags in the instrumentation. ${ }^{12}$ Despite the persistence in the residuals, a set of valid instruments must also be assumed to be exogenous to conclude the validity of the system GMM. In an attempt to verify this assumption, we analyse both the Sargan (1958) and Hansen (1982) tests. The Hansen test proposes an optimal weighting matrix that can be estimated in a two-step procedure. The problem with this test is that it is weakened by instrument proliferation. In contrast, the Sargan test is not weakened but the weighting matrix that it employs is a consistent estimator of the covariance matrix of the errors only under homoskedasticity. Otherwise, the Sargan test tends to over-reject the null.

The results for the sample, DCC, and DCCD estimates are displayed in Tables 3, 4, and 5, respectively. These tables show results regarding a selection of models that exclude the explanatory variables that are statistically irrelevant for the three sets of correlations

\footnotetext{
${ }^{11}$ We check that an autoregressive process of first order is sufficient for capturing the persistence in DCC and DCCD estimates. For the sample correlations, more lags may be needed, but for the sake of homogeneity in comparisons and to be parsimonious in the number of instruments, we choose to include only one lag of the dependent variable for all cases.

${ }^{12}$ To control for the lack of information when too few lags are employed a second alternative is to estimate the model by collapsing the instrument set following Roodman (2009). Collapsing the instrument set allows all possible lags to be employed but reduces the standard number of moment conditions by linear combinations. This method conveys slightly less information than the standard one while embodying the same expectation in the moment condition set. We repeat the estimation using this collapsed method and conclusions remain equal. Tables are available upon request.
} 
analysed. ${ }^{13}$ Additionally, we do not include simultaneously variables with potential problems of multicolinearity. ${ }^{14}$ Tables 3, 4, and 5 report the estimated slopes and two-step robust $p$ values (in parentheses) based on the Windmeijer (2005) correction. The number of instruments is reported at the top of each column. Different-order Arellano-Bond, Sargan, and Hansen tests are reported in the bottom rows. Based on the Arellano-Bond and Hansen tests, we use the second lag of the dependent variables in Tables 4 and 5, while the instruments are lags from five to seven for the sample correlations.

\section{[Tables 3, 4 and 5]}

The results are quite robust for the different methods employed for estimating correlations. Therefore we discuss the results in Tables 3 to 5 as a whole. Starting with the global specification point of view, we find that the null of the absence of second-order autocorrelation is not rejected by the Arellano-Bond test for correlations estimated with DCC and DCCD methods. In the case of the sample correlation, an AR(5) specification is needed for no serial correlation in the residuals and thus lags of five and up are valid instruments. Comparisons between different sets of instruments by the differences in the Hansen test indicate that lags from five to seven are appropriate. The Hansen test does not reject the null that the overidentifying restrictions are valid for all different models and the three estimated groups of correlations. Finally, the Sargan test rejects the null for all models in all tables. The comparison between the Hansen and Sargan statistic values suggests that the weighting matrix in the Sargan statistic undervalues the error covariance matrix, making problematic inference from using a chi-squared distribution in this case.

Regarding the estimates of the model parameters and starting with the autoregressive component, it is clearly significant in all cases showing higher values in the case of the sample correlations. This fact confirms the adequacy of the selection of a dynamic GMM model. With respect to the set of state variables, the most consistent result refers to the volatility of consumption growth. Its relation with the stock-bond correlation is negative and highly significant for all models in Tables 4 and 5. In the case of the sample correlations, their relation with the consumption volatility is weaker but is also significant in models that

\footnotetext{
13 They are GDP growth, IPI growth, consumption growth, the volatility of the market index, the illiquidity measures for either the stock or the bond in the pair, the coupon level and the covenant indicator.

${ }^{14}$ In that sense, we have found that the information in short-term interest rates or the NBER dummy variable is already included in the term spread and/or default spread, levered and unlevered betas are highly correlated but results for unlevered beta are more stable, and the total risk and the idiosyncratic risk share an important part of common information and the former is not significant when the non-systematic risk is considered in the model.
} 
do not include Term or Default spreads. Therefore, it seems that the aggregate consumption risk determines not only stock prices but also bond prices, being a relevant factor for explaining the correlation between the two assets. This result would be in favor of consumption-based models simultaneously pricing stock and corporate bonds, as that of Bhamra, Kuehn, and Strebulaev (2010). The negative sign indicates that a macroeconomic negative shock, measured by an increase in consumption volatility, conversely affects the bond and stock returns, decreasing the correlation between them.

The other variables representing economic cycles produce less stable results but suggest a similar conclusion. Generally speaking, negative expectations, as indicated by the aggregate default spread, are also significantly related to a decrease in correlations. The relation between correlations and the Term spread is not stable, with both the parameter sign and the significance changing depending on the model. Finally, VIX is a weak explanatory variable that is only significant in some models with a positive sign, in general. We return to this finding later.

Summarizing the results regarding all the variables that convey information about the economic cycles, we find that stocks and bonds issued by the same firm react differently depending on the type of news. News about macroeconomic growth (IPI growth, consumption growth, or GDP growth) does not explain the correlations' variability and only news regarding risk can be associated with correlations. The negative sign of this association indicates that good news from aggregate risk indicators could be interpreted as a signal of an increase in the firm value and thus both the equity and debt values would increase, producing an increment in the correlation between their returns. However, bad news would affect the two assets asymmetrically, probably because of the different sensitivities of stocks and bonds to aggregate risk shocks.

Regarding variables with firm-specific information, again the risk variables are the most related to changes in the correlations. For the three correlation estimate sets and the different system instrumentations, we find that the higher the idiosyncratic risk, the more the stock-bond correlation increases. With the exception of the sample correlations, the same is also true for the leverage ratio. These findings are consistent, on the one hand, with structural models which predict a positive relation between the stock-bond correlation and the firm risk that will be stronger when leverage is higher. On the other hand, our results also agree with previous empirical evidence confirming that the relation between the two assets strengthens 
as issuer risk increases (Campbell and Taskler, 2003; Campello, Cheng and Zhang, 2008; Schaefer and Strebulaev, 2008). Finally, it seems that the firm probability of default is not generally related to the correlations.

Other variables that also approximate the firm risks lead to different conclusions. Systematic operational risk, measured by unlevered beta, is strong and negatively related to correlations estimated with GARCH-type models. This result also holds, although more weakly, in the case of sample correlations. It suggests that, in contrast to the idiosyncratic risk, increases in the systematic risk (especially in its operational component) are incorporated in the stock price but not in the bond price, thereby reducing the correlation.

Finally, we also find that the type of industry appears to be an important determinant of the correlation; the correlation is higher for utility firms than for the other two industries and is significantly reduced for industrial firms. In addition, for some correlation estimates and certain models, the correlation is higher when the bond's time to maturity is longer.

\subsection{Fama-MacBeth estimation}

To ensure the reasonableness of our conclusion from the panel data estimation in the previous section, we run cross-sectional regressions each month and compute estimates and standard errors following Fama and MacBeth (1973). The results are shown in Table 6. In this case, the state variables cannot be included in the regression and we consider all possible combinations of the variables with cross-sectional dispersion.

\section{[Table 6]}

All the conclusions from the panel data estimation can be again extracted from the Fama-MacBeth estimation results. Once again leverage and idiosyncratic risk are positive and significantly related to correlations; the higher the unlevered market betas, the lower the correlations will be; and correlations are higher when the bond time to maturity is longer and for firms in the utility sector. In addition, we now find that the firm default probability is relevant in determining the correlation with a positive sign in some cases. Therefore, we can conclude that increases in specific (non-systematic) firm risk are contemporaneously associated with increases in the correlation between the firm's bond and stock returns. 


\subsection{Interactions}

Given the previous results showing inconsistencies in the estimation of the relationship between stock-bond correlations and variables like VIX or default probability, we now investigate if these inconsistencies are related to interactions between aggregate risk (economic cycle indicators) and individual firm risk (firm characteristics measuring risk). We analyse this possibility with the theoretical support of the theoretical model proposed by Bhamra, Kuehn, and Strebulaev (2010) that combines the time series and cross-sectional dimensions of the problem. Under this model, the sources of risk for both stocks and bonds are aggregate consumption and the earnings of the firm. On the one hand, negative changes in the next period's consumption growth or a negative revision in expectations about consumption growth in the future increases the price of risk, which would have negative consequences for both the stock and the bond. On the other hand, firm earnings volatility is responsible of the price of the default claim; while an increase in firm risk would have a negative effect on bond price, its effect on the stock price is a priori ambiguous because it is also affected by the call structure of the equity value. Moreover, these two sources of risk are positively correlated. ${ }^{15}$ Within this framework, we would expect interactions between state or aggregate variables and variables related to firm risk.

We split the sample of firms into two subsamples on the base of the firm default probability. Specifically, each month in our sample period we classify a firm as having a high probability of default if its probability of default is higher than the 75 th percentile for the cross-sectional distribution of that month. Otherwise, the firm is in the low (normal) default probability subsample. ${ }^{16}$ Now, we repeat the panel estimations for each subsample separately. The estimated results are reported in Tables 7 and 8 for the low and high default probability subsamples, respectively.

[Tables 7 and 8]

\footnotetext{
15 The estimations in Bhamra, Kuehn, and Strebulaev (2010) produce a correlation of 20 percent between the Brownian motion in the consumption growth dynamics and the systematic shocks to the firm's earnings growth. ${ }^{16}$ We adopt this method of splitting the sample because it produces the highest differences in the mean level of default probability between the subsamples. In addition, this division produces the most symmetric distribution of firms: the median number of firms in each subsample is exactly the same. After that, the number of stockbond correlations in each subsample depends on the number of bonds belonging to each firm and, of course, on the specific month. On average, over time, the number of correlations is 165 in the high default probability subsample and 300 in the low default probability subsample, with a maximum of 239 firms in the former subsample in November 2008.
} 
The results confirm our suspicion of interaction between aggregate cycle indicators and the firm's specific position of risk. The most important difference between the results in Tables 7 and 8 is the role of state variables in determining the time dynamics of correlations. When the probability of default is low, the volatility of consumption growth is again clear and negatively related to the correlations and increases in the aggregate default spread are also related to decreases in the correlations. However, for firms with a high probability of default, the volatility of consumption loses its importance. Regarding variables representing cross-sectional dispersion, on the one hand, and consistent with results for the whole sample, we find that the idiosyncratic stock risk and the leverage ratio are both positively related to correlations in both subsamples. Therefore, we can again conclude that increases in variables related to firm-specific risk are associated with increases in the correlation. On the other hand, estimates for the unlevered beta are negative and significant in both subsamples, although they are higher in absolute value and have lower standard errors in the sub-group of firms with a high probability of default. Understanding that the systematic risk is measured as the sensitivity of the stock to changes in an aggregate risk factor, its negative relation with the correlations could be justified in the same way as the effect of the state variables. Other differences between results in Tables 7 and 8 are that the dummy associated with the financial sector (industry 2) is only significant in the high default probability subsample and the bond time to maturity only matters if the firm is in the low default probability subsample. These results explain the instability in the $t$-statistics of these two variables for the whole sample.

An interesting result is associated with VIX. We find that it does not contain information about the variability of correlations in the subsample of firms with a low probability of default but it turns out to be very important for firms with a high probability of default, where it explains correlations with a positive sign. Taking into account the fact that our sample period is relatively short and includes the recent crisis, we analyse the serial correlation between VIX and the cross-sectional average of the idiosyncratic stock risk. We find that the correlation between the proxy for the whole stock market's risk and the average of the variables measuring firm idiosyncratic risks is 0.885 . Moreover, the firms with the highest probability of default are also those with the highest idiosyncratic risk. Therefore, in this context, it is not surprising that the correlation between stock and bond returns increases when VIX increases. 
Finally, it is important to point out that the whole specification of the models improves when they are estimated in the two subsamples separately.

\section{Adjustments to target leverage and the stock-bond correlation}

The results in Section 5 point out that the time variation of stock-bond correlations is not significantly related to standard cycle indicators; only the volatility of aggregate consumption growth (and default spread in some cases) is negatively associated with the correlation, but the significance of this relation disappears for firms with a high probability of default. In contrast, both cross-sectional and time series differences between correlations can be explained by firm characteristics indicating firm risk. Especially important is the relation between firm leverage and the stock-bond correlation. On the one hand, as discussed in Section 2, structural models, represented by expression (5), suggest a relation (positive, on average) between stock and bond returns that gets stronger as the firm's leverage increases. Thus, the cross-sectional association between leverage and correlation can thus be theoretically justified. On the other hand, models assuming agency costs that recognize the reduction in information asymmetry produced by the use of debt predict a positive relation between leverage and firm value. Combining this result with the fundamental assumption of structural models that equity and debt values are positive functions of firm value, a serial positive correlation between the leverage ratio and the stock-bond correlation can also be theoretically supported.

In this section, we rely on the strong relation we find in Section 5 between the leverage ratio and the correlation to test the implications of the trade-off theory, with the novelty proposal of incorporating the information embedded in the stock-bond correlation. Specifically, we analyse what role the correlation can play in firm adjustments towards target leverage.

Studies on corporate finance suggest that capital structure varies both crosssectionally and in time series. Debt ratios vary with firm characteristics, with larger firms with more tangible assets having higher debt ratios, while more profitable firms with high book-to-market ratios and high research and development expenses use less debt financing (for a recent survey, see Parsons and Titman, 2009). This variation in capital structure is compatible with the traditional point of view that firms strive to maintain an optimal capital structure, a target leverage. However, while authors such as Hovakimian, Opler, and Titman (2001) and Flannery and Rangan (2006) suggest time-varying targets, Lemmon, Roberts, and 
Zender (2008), for example, divide capital structure into two components: a permanent component of capital structure, the target, which is surprisingly stable, and a transitory component, formed by shocks or events in a firm's life that make its leverage ratio deviate from the target ratio. Such shocks include, for example, market timing opportunities in which some types of financing are cheaper. After the shocks, companies rebalance their leverage to converge to the target. In this sense, the literature is in complete agreement about the mean reversion behaviour of leverage but presents different conclusions about how quickly leverage reverts to its target ratio. Depending on the importance of the target capital structure for a firm, shocks should be quickly corrected and the company should quickly achieve its leverage target.

The significant and strong relation between the variation in firm leverage ratio and that in the stock-bond correlation this study finds suggests that the correlation could be associated with the transitory component of capital structure and, therefore, should play an important role in a dynamic model for firm leverage adjustments. Therefore, we hypothesize that the level of the correlation between the stocks and bonds of the same firm can help understand how firms dynamically adjust their capital structure. The adjustment speed towards the target debt ratio should be greater for firms and periods with positive stock-bond correlations.

Empirical evidence regarding the dynamic adjustment of capital structure documents different speeds of adjustment towards the target debt ratio for different firms. Fama and French (2002) indicate that firms' debt ratios adjust slowly. Flannery and Rangan (2006) report a relatively fast speed of adjustment towards the target debt ratio of 35 percent per year. However, Faulkender, Flannery, Hankins, and Smith (2012) note that the speed of adjustment depends on the firm's access to external financing and ranges from 31 percent for firms with access to external markets to 17 percent for firms with more restrictive access to capital markets. Similarly, Byoun (2008) finds that the speed of adjustment is lower for firms with market debt ratios below their target level and binding financial constraints. Finally, additional papers provide evidence that the adjustment speed is time varying and is significantly related to macroeconomic conditions (Drobetz and Wanzenried, 2006; Drobetz, Pensa, and Wanzenried, 2007; Cook and Tang, 2010). In this sense, firms would adjust their debt ratios towards target leverage more quickly in good macroeconomic states relative to bad states. 
The basic model proposed by Flannery and Rangan (2006) for the leverage ratio of the firm $j$ is

$$
L e v_{j t}-L e v_{j t-h}=\lambda\left(L e v_{j t}^{*}-L e v_{j t-h}\right)+u_{j t}
$$

where $\lambda$ is the speed of adjustment towards the leverage target, which is usually defined as a function of the past values of some $K$ firm characteristics,

$$
L e v_{j t}^{*}=\sum_{k=1}^{K} \beta_{k} X_{k j t-h}
$$

This basic model assumes that all firms have the same adjustment speed. Using the theoretical framework of the structural models with agency costs discussed in Section 2, our argument is that the adjustment speed changes both across firms and in time and, given the positive relation between leverage and the stock-bond correlation, that the adjustment will be more rapid for firms and periods of positive correlation. That is, we assume

$$
\lambda_{j t}=\lambda_{0}+\lambda_{1} q_{i j t}+e_{j t}
$$

where $q_{i j t}$ is the correlation level of the stock-bond pair $i$ for firm $j$ and period $t$ and $e_{j t}$ is uncorrelated to the value of any firm characteristic (including leverage) in period $t-h$.

Combining equations (11) to (13), we find the full specification of the model to be

$$
\operatorname{Lev}_{j t}=\left(1-\lambda_{0}\right) L e v_{j t-h}-\lambda_{1} q_{i j t} \operatorname{Lev}_{j t-h}+\sum_{k=1}^{K} \gamma_{k} X_{k j t-h}-\sum_{k=1}^{K} \delta_{k} q_{i j t} X_{k j t-h}+\varepsilon_{j t}
$$

where $\gamma_{k}=\lambda_{0} \beta_{k}, \delta_{k}=\lambda_{1} \beta_{k}$ and $\varepsilon_{j t}=e_{j t}\left(\sum_{k=1}^{K} \beta_{k} X_{k j t-h}-L e v_{j t-h}\right)+u_{j t}$. Note that if $\lambda_{1}=0$, the speed of adjustment would be constant and the basic model would be recovered.

Table 9 reports the results of fixed effects panel estimation for several models nested in equation (14). ${ }^{17}$ The $t$-statistics are shown in parentheses and the last row indicates whether year dummies are included. We use quarterly data and, therefore, four lags are considered for leverage adjustments $(h=4)$. Variables used as the determinants of the target leverage are standard firm characteristics employed in the previous literature and are described in Section 3. The quarterly correlation series are the averages for all days in the quarters of the DCC estimates.

\footnotetext{
${ }^{17}$ Equation (14) is estimated in differences to reduce the bias due to highly persistent dependent variables.
} 
The first two models in Table 9 are estimated to identify which firm characteristics are relevant determinants of a firm's optimal leverage. As seen, the time dummies are necessary to obtain the expected signs and also for stronger relations. High values of ROA, BMT, and IC are associated with low leverage the next year and larger firms show larger leverage ratios. Tax rates and the percentage of intangibles in total assets do not seem to be relevant. The inclusion of the lagged leverage in model (3) clearly confirms the firm's desire for optimal leverage ratios. The parameter is clearly different from zero and represents a fast adjustment of about 30 percent per year. ${ }^{18}$ In addition, TAX and Intang are now significant and have the expected signs; the higher the tax rate, the higher the benefits of debt financing and firms with a high proportion of intangible assets have higher bankruptcy costs and then lower leverage ratios. In contrast, ROA is not relevant when the lagged leverage is considered. A previous correlation analysis reveals high and positive correlations between BTM, ROA, and TAX, on the one hand, and a negative correlation between BTM and Size, on the other hand. This prevents us from including all the firm variables simultaneously in the following models.

Models (4) to (10) refer to different specifications of equation (14), including our proposal of different adjustment speeds for different stock-bond return correlations. The slope of the product of lagged leverage and the correlation is statistically significant in all models, confirming our conjecture that the correlation can help understand how the adjustment speed changes with time and across firms. This varying pattern can explain, at least partially, the different results of previous papers. We find a negative slope, which implies a positive relation between the correlation and the adjustment speed; that is, the higher the correlation between the two firms' financing sources, the faster the adjustment towards the target. When the correlation is near zero, the firm's capital structure restructuring must make adjustments to the target. However, if, additionally, the market values of equity and debt react in the same direction because of the capital restructuration news, the leverage objective can be achieved earlier. Therefore, given the results about the determinants of the

\footnotetext{
18 This level of adjustment speed is similar to the values reported by Flannery and Rangan (2006) and contradicts other papers that provide much lower speeds. We also employ GMM system estimation and find the parameter associated with the lagged leverage is higher (lower speed) but the results are qualitatively the same for all models in Table 9.
} 
correlation in the previous section, we conclude that the adjustment speed will be higher for firms with high leverage ratios, high idiosyncratic risk, or in the utility industry and when high future market risk is expected. Our evidence is consistent with the findings of Byoun (2008).

\section{Summary and conclusions}

The correlation between bond and stock returns at the aggregate market level is a widely investigated topic. However, papers seeking to explain the commonality between the bond and stock returns of assets issued by the same firm are scarce, perhaps because of the lack of a continuous and reliable database for corporate bond transaction prices. We attempt to fill this gap. Moreover, the analysis of the correlation between stock and bond returns at the individual level is especially important for dynamic capital structure decisions given the potential effects of these correlation on the speed of adjustment towards target leverage.

The first part of the paper estimates the correlation series for each stock-bond pair in our sample and identifies the sources of the variability of these correlations over time and across firms and/or bond issues. We employ corporate bond transaction prices from TRACE and use different approaches: a rolling window sample correlation, a DCC model, and a variation of the previous model to incorporate the non-synchronous trading problem. Our results indicate that the correlations between individual bond and stock returns are small, on average, but definitively time varying. The dynamics in the correlations are reasonably well captured by persistence models and non-trading adjustments can have an important effect on the correlation dynamics for relatively illiquid bonds. Regarding the determinants of the correlations, we consider a large set of potential explanatory variables, including economic cycle indicators, different measures of issuer risk, and specific bond contract-related characteristics. We employ both panel data analysis and the Fama-MacBeth cross-sectional estimation methodology and evaluate the explanatory power of the variables in the whole sample of firms as well as in sub-samples split by levels of the firm probability of default. We find that variables approximating macroeconomic growth are not related to the correlations. Only variables indicating increases in aggregate risk, such as the volatility of consumption growth or the aggregate default premium, are related to decreases in the correlations. However, this association is weaker for the subsample of firms with a high probability of default. In contrast, measures of firm-specific risk are significantly related to changes in the correlations, with effects that change depending on the type of risk. While the correlation 
decreases when systematic firm risk increases, it increases with idiosyncratic risk. Especially robust are the relations between the correlation and idiosyncratic stock volatility or the financial leverage ratio. Therefore, as for structural models, we can conclude that there are common factors that pressure both stock and bond prices in the same direction.

The positive and significant relation between the correlation and the leverage ratio suggests that the correlation contains information about the firm target leverage or about the way in which this target can be achieved. The capital structure literature concurs about a dynamic rebalancing of firm leverage towards the target but differs about the speed of adjustments. Our last contribution is the proposal of a leverage adjustment model in which the adjustment speed changes both across firms and in time and this varying pattern is modelled as a function of the stock-bond correlation. The estimation of the model shows that the higher the correlation between the two firms' financing sources, the faster the adjustment towards the target.

\section{Acknowledgments}

Helpful comments by the participants in the XIX Finance Forum and the $2^{\text {nd }}$ International Conference of Financial Engineering and Banking Society are gratefully acknowledged. Special thanks are for Gonzalo Rubio. Belen Nieto acknowledges financial support from the Spanish Department of Science and Innovation through grant ECO2011-29751 and from Generalitat Valenciana through grant PROMETEOII/2013/015. Rosa Rodríguez acknowledges financial support from the Ministry of Economics and Competitiveness through grant ECO2012-36559.

\section{References}

Abad-Romero P. and M. D. Robles. 2006. Risk and return around bond rating changes: New evidence from the Spanish stock market. Journal of Business Finance \& Accounting 33(5-6): 885-908.

Amihud, Y. 2002. Illiquidity and stock returns: Cross-section and time-series effects. Journal of Financial Markets 5 (1): 31-56.

Andersson, M., E. Krylova, and S. Vähämaa. 2008. Why does the correlation between stock and bond returns vary over time? Applied Financial Economics 18(2): 139-151.

Arellano, M. and S. Bond. 1991. Some tests of specification for panel data: Monte Carlo evidence and an application to employment equations. Review of Economic Studies 58: 277-297.

Arellano, M. and O. Bover. 1995. Another look at the instrumental variables estimation of error components models. Journal of Econometrics 68: 29-51.

Baele, L., G. Bekaert and K. Inghelbrecht. 2010. The determinants of stock and bond return comovements. The Review Financial Studies 23 (6): 2374-2428. 
Barron, M. J., A. D. Clare and S. H. Thomas. 1997. The effect of bond rating changes and new ratings on UK stock returns. Journal of Business Finance and Accounting 24(34): 497-509.

Bessembinder, H., W. Maxwell and K. Venkaraman. 2006. Market transparency, liquidity externalities, and institutional trading costs in corporate bonds. Journal of Financial Economics 82: 251-288.

Bhamra, H. S., L. Kuehn, and I. A. Strebulaev. 2010. The levered equity risk premium and credit spreads: A unified framework. Review of Financial Studies 23(2): 645-703.

Blouin, J., J. E. Core and W. Guay. 2010. Have the tax benefits of debt been overestimated?. Journal of Financial Economics 98(2): 195-213.

Blundell, R. and S. Bond. 1998. Initial conditions and moment restrictions in dynamic panel data models. Journal of Econometrics 87: 11-143.

Byoun, S. 2008. How and when do firms adjust their capital structure toward targets? Journal of Finance 63: 3069-3096.

Campbell, J. and G. Taskler. 2003. Equity volatility and corporate bond yields. Journal of Finance 58: 2321-2349.

Campello, M., L. Cheng and L. Zhang. 2008. Expected returns, yield spreads, and asset pricing tests. Review of Financial Studies 21: 1297-1338.

Connolly, R., C. Stivers and L. Sun. 2005. Stock market uncertainty and the stock-bond return relation. Journal of Financial and Quantitative Analysis 40: 161-194.

Cook, D. and T. Tang. 2010. Macroeconomic conditions and capital structure adjustment speed. Journal of Corporate Finance 16(1): 73-87.

Cremers, M., J. Driessen, P. Maenhout and D. Weinbaum. 2008. Individual stock-option prices and credit spreads. Journal of Banking and Finance 32(12): 2706-2715.

D'Addona, S. and A. Kind. 2006. International stock-bond correlations in a simple affine asset pricing model. Journal of Banking and Finance 30(10): 2747-2765.

Demiralp, I. and S. Hein. 2010. Debt default risk and the correlation of stock returns and bond yield changes. Working paper, available at http://ssrn.com/abstract=1650739.

Dick-Nielsen, J. 2009. Liquidity biases in TRACE. Journal of Fixed Income 19(2): 43-55.

Dick-Nielsen, J., P. Feldhütter and D. Lando. 2012. Corporate bond liquidity before and after the onset of the subprime crisis. Journal of Financial Economics 103(3): 471-492.

Drobetz, W. and G. Wanzenried. 2006. What determines the speed of adjustment to the target capital structure? Applied Financial Economics 16(13): 941-958.

Drobetz, W., Pensa, P. and G. Wanzenried. 2007. Firm characteristics, economic conditions and capital structure adjustment. SSRN Electronic Journal. Available at: http://papers.ssrn.com/sol3/papers.cfm?abstract_id=924179

Edwards, A. K., L. E. Harris and M. S. Piwoward. 2007. Corporate bond market transaction cost and transparency. Journal of Finance 62: 1421-1451.

Elkamhi, R. and J. Ericsson. 2008. Time varying risk premia in corporate bond markets. Working paper, available at http://ssrn.com/abstract=972636.

Engle, R. F. 2002. Dynamic conditional correlation: A simple class of multivariate generalized autoregressive conditional heteroskedasticity models. Journal of Business and Economic Statistics 20: 339-350.

Engle, R. F., A. Kane and J. Noh. 1996. Index-option pricing with stochastic volatility and the value of accurate variance forecasts. Review of Derivatives Research 1(2): 139157.

Fama, E. and K. French. 2002. Testing trade-off and pecking order predictions about dividends and debt. Review of Financial Studies 15(1): 1-33.

Fama, E. F., and J. D. MacBeth. 1973. Risk, return, and equilibrium: Empirical tests. Journal of Political Economy 71: 607-636. 
Faulkender, M., M. Flannery, K. Hankins and J. M. Smith. 2012. Cash flows and leverage adjustments. Journal of Financial Economics 103(3): 632-646.

Flannery, M. J. and K. P. Rangan. 2006. Partial adjustment toward target capital structures. Journal of Financial Economics 79(3): 469-506.

Goldstein, M. A., E. E. Hotchkiss and E. R. Sirri. 2007. Transparency and liquidity: A controlled experiment on corporate bonds. Review of Financial Studies 20: 235-273.

Gulko, L. 2002. Decoupling. Journal of Portfolio Management 28: 59-66.

Hansen, L. 1982. Large sample properties of generalized method of moments estimators. Econometrica 50 (3): 1029-1054.

Harris, M. and A. Raviv. 1990. Capital structure and the information role of debt. Journal of Finance 45: 321-349.

Holthausen, R. and R. Leftwich. 1986. The effect of bond rating changes on common stock prices. Journal of Financial Economics 17: 57-89.

Hovakimian, A., T. Opler and S. Titman. 2001. The debt-equity choice. Journal of Financial and Quantitative Analysis 36(1): 1-24.

Illmanen, A. 2003. Stock-bond correlations. Journal of Fixed Income 13(2): 55-66.

Jensen, M. 1986. Agency costs of free cash flow, corporate finance and takeovers. American Economic Review 76: 323-329.

Jensen, M. and W. Meckling, 1976. Theory of the firm: Managerial behavior, agency costs and ownership structure. Journal of Financial Economics 3(4): 305-360.

Kayhan, A. and S. Titman. 2007. Firms' histories and their capital structures. Journal of Financial Economics 83(1): 1-32.

Korajczyk, R. and A. Levy. 2003. Capital structure choice: macroeconomic conditions and financial constraints. Journal of Financial Economics 68(1): 75-109.

Lemmon, M., M. Roberts, and J. Zender. 2008. Back to the beginning: Persistence and the cross-section of corporate capital structure. Journal of Finance 63: 1575-1608.

Merton, R. 1974. On the pricing of corporate debt: The risk structure of interest rates. Journal of Finance 29: 449-470.

Modigliani, F. and M. Miller. 1963. Corporate income taxes and the cost of capital: A correction. American Economic Review 53(3): 433-492.

Myers, S. 1977. Determinants of corporate borrowing. Journal of Financial Economics 5: $147-175$.

Parsons, C. and S. Titman. 2009. Empirical capital structure: A review. Foundations and Trends in Finance 3(1):1-93.

Roodman, D. 2009. A note on the theme of too many instruments. Oxford Bulletin of Economics and Statistics 71(1): 135-158.

Sargan, J. 1958. The estimation of economic relationships using instrumental variables. Econometrica 26(3): 393-415.

Schaefer, S. M. and I. A. Strebulaev. 2008. Structural models of credit risk are useful: Evidence from hedge ratios on corporate bonds. Journal of Financial Economics 90: $1-19$.

Scott, J. 1976. A theory of optimal capital structure. Bell Journal of Economics 7: 33-54.

Stulz, R. 1990. Managerial discretion and optimal financing policies. Journal of Financial Economics 26: 3-27.

Titman, S. 1984. The effect of capital structure on a firm's liquidation decision. Journal of Financial Economics 13: 137-151.

Windmeijer, F. 2005. A finite sample correction for the variance of linear efficient two-step GMM estimators. Journal of Econometrics 126: 25-51. 
Zhang, B. Y., H. Zhou and H. Zhu. 2009. Explaining credit default swap spreads with the equity volatility and jump risks on individual firms. Review of Financial Studies 22: 5099-5131. 


\section{Appendix: Potential determinants of correlations variability}

\section{State variables}

$\triangle$ GDP: The growth rate of GDP comes from monthly real GDP index provided for macroeconomic advisers.

$\Delta$ IPI: The IPI growth rate is computed from the monthly index provided in Table G.17 of the Federal Reserve database, which is constructed from the major industry groups.

$\Delta \mathrm{c}$ : The aggregate consumption growth is computed from seasonally adjusted monthly data on real consumption expenditures on non-durable goods and services in national income and product accounts Table 2.8.6 from the U.S. Bureau of Economic Analysis.

NBER: A dummy variable that is equal to one during recessions and zero otherwise and is constructed from the recession dates provided by the National Bureau of Economic Research.

$\sigma_{\mathrm{c}}$ : The volatility of aggregate consumption growth is computed using a rolling window of 36 previous months.

$\sigma_{\mathrm{SP}}$ : The volatility of the stock market is computed monthly from the daily stock returns of the S\&P 100 and a past rolling window of 60 observations.

VIX: As a proxy for the aggregate stock market risk, we use monthly data for the volatility index (VIX) obtained from the Chicago Board of Options Exchange.

Default: The default premium proxy variable is computed as the spread between Moody's yield on BAA corporate bonds and the yield on U.S. Treasury 10-year securities.

Tbill: As a proxy for the risk-free rate, we use the three-month Treasury bill secondary market rate, from the Federal Reserve's database, Table H.15.

Term: The term structure variable is computed as the difference between the market yield on U.S. Treasury securities at a 10-year constant maturity and the three-month Treasury bill rate.

\section{Individual stock uncertainty}

$\sigma^{\text {Tot: }}$ Stock total risk is computed as the standard deviation of stock returns.

$\beta$ and $\beta_{\mathrm{FF}}$ : Systematic risk is measured by the market beta from the market model and the Fama and French (1993) model.

$\sigma^{\mathrm{Id}}$ and $\sigma_{\mathrm{FF}}^{\mathrm{Id}}$ : Idiosyncratic risk measures are computed as the standard deviation of the residuals from the market model or the Fama-French model.

Monthly measures of stock risk are computed using daily stock returns and a past rolling window of 60 observations. 


\section{Firm financial risk}

Lev: The leverage ratio is measured as the ratio between the book debt from Compustat ${ }^{19}$ and the market equity from the Center for Reasearch in Security Prices (CRSP). The debt value is reloaded quarterly because of availability reasons, while the equity value is measured monthly as the number of shares outstanding multiplied by the price at the end of the month.

Default Prob: Monthly series for the default probability of each firm have been provided by Moody's.

\section{Firm operational risk}

Ind1 and Ind2: To control for commonality in operational risk between issuers, we include two dummy variables for distinguishing the three industries in our sample: industrial, financial, and utility firms. The variable Ind1 equals one if the issuer is an industrial firm, including manufacturing, communications, oil and gas, retail, service/leisure, and transportation; Ind2 includes banking, credit/financing, financial services, and insurance firms. In the third industrial group (without dummy representation) are electric, gas, and telephone service suppliers.

$\beta^{\mathrm{UN}}$ and $\beta_{\mathrm{FF}}^{\mathrm{UN}}$ : Unlevered betas are computed from the market beta using the ModiglianiMiller (1963) relationship,

$$
\beta_{j t}^{U}=\frac{\beta_{j t}}{1+\left(1-T_{j t}\right) L_{j t}}
$$

where $T_{j t}$ is the tax rate and $L_{j t}$ the financial leverage ratio for firm $j$ at month $t$. We estimate two unlevered betas using the two measures of market betas, assuming the CAPM or the Fama-French model. To measure financial leverage we use our variable Lev.

We estimate corporate marginal tax rates (MTRs) annually and use these estimations for all months within this year. The dynamic features of the tax code makes it unrealistic to compute the MTR for a given firm and year as the rate between taxes and taxable earnings. The tax code allows firms to carry losses back and forward. This means that if current taxable income is shielded by current interest deductions, an extra dollar of interest leads to a loss today that can be carried back to obtain a refund of taxes paid in the past or that can be carried forward to shield profits in future years. Then, it is important to consider an uncertain scenario with past and future earnings to estimate the MTR for each firm and year.

We estimate the MTR following Graham (2000) and Binsbergen, Graham, and Yang (2010). For each firm and year, a scenario containing past and future earnings is simulated from the observed current taxable income. Given this simulated scenario, the tax bills for all years in the scenario are computed. Next, the current taxable income is increased by one unit $(\$ 10,000$ in terms of Compustat units) and the tax bills for all simulated years are recalculated. The present value of the difference between the tax bills in the first simulation and the tax bills in

\footnotetext{
${ }^{19}$ Specifically, we employ long-term debt and not total liabilities because not all quarterly data on debt in current liabilities are available from Compustat for some firms.
} 
the incremental simulation represents the MTR rate for this firm, year, and specific scenario. The exercise is repeated for a number of different scenarios or paths and the average across the MTRs is the estimation of the expected MTR.

The specific details for the application of the estimation technique are as follows. The simulated taxable incomes paths are generated assuming that they change according to a normal distribution with mean and variance equal to the historic mean and variance of the series. These historical moments are computed for each year $t$ using historical data from 1979 to year $y-1 .^{20}$ Each simulated scenario contains 23 years: the current year with the observed taxable income, two years back, and 20 years forward. ${ }^{21}$ Based on the current statutory federal tax schedule, the deduction for $\$ 1$ initial interest is $0.35 .^{22}$ For computing present values, taxes in the years $y+1$ through $y+20$ are discounted using the yield of corporate bonds in year $y$. Specifically, we employ as the discount rates two indexes of corporate bond yield provided by the Federal Reserve for 2002-2009: Moody's yield on seasoned AAA corporate bonds and Moody's yield on seasoned BAA corporate bonds. The first index is used to discount the estimated future differences in tax bills for firms classified as level A for all the years in our sample and the second index is employed for firms with a rating level lower than A in any year of our sample. The difference in tax bills for years $y-1$ and $y-2$ are not grossed up because tax refunds are not paid with interest. We consider 50 paths.

For robustness reasons, we use two alternative measures of the corporate tax rates in computing the unleveraged betas: the tax rate directly provided by Compustat, which is computed annually as the rate between total taxes and pre-tax income, and the rate between total taxes and earnings before interest and taxes. We impose a zero tax rate when it is negative.

We then have three measures of tax rates that produce three series for $\beta^{\mathrm{UN}}$ and three series for $\beta_{\text {FF. }}^{\mathrm{UN}}$

\section{Bond agency problem}

Cov: We construct a covenant intensity index following Demiroglu and James (2010). It is defined as the sum of the number of covenants for each bond contract, including both covenants that restrict the ability of the issuer to take part in a transaction that may be detrimental to bondholders and covenants designed to directly protect bondholders.

\section{Bond and stock illiquidity}

$\mathrm{Ami}_{\mathrm{S}}$ and $\mathrm{Ami}_{\mathrm{B}}$ : For each stock and bond, the illiquidity ratio is calculated daily as the ratio of the absolute value of the daily return over the dollar volume, which is closely related to the notion of price impact,

\footnotetext{
${ }^{20}$ When the historic mean is negative, the mean of the normal distribution is assumed to be zero.

${ }^{21}$ Since 1997, tax law allows firms to carry losses back two years or forward 20 years.

${ }^{22}$ We do not incorporate state taxes in the estimation of the MTR because many additional assumptions can be made, since each state has its own graduated rate structure and its own definition of variables with which to compute state taxes.
} 


$$
I l i q_{d}=\frac{\left|R_{d}\right|}{D V o l_{d}}
$$

where $\left|R_{d}\right|$ and $D V o l_{d}$ are the absolute return and the dollar trading volume of the asset during day $d$. This measure is averaged monthly to obtain an individual illiquidity measure for each asset at month $t$,

$$
\text { Illiq }_{t}=\frac{1}{D_{t}} \sum_{d=1}^{D_{t}} \frac{\left|R_{d}\right|}{D V o l_{d}}
$$

Where $D_{t}$ is the number of days for which data about asset are available in month $t$. Daily returns and trading volumes (in millions of dollars) for the stocks in our sample are collected from the CRSP. In the case of bonds, daily returns and volumes are from the TRACE database.

\section{Bond issue characteristics}

Time: The time to maturity is computed monthly as the number of days until maturity.

Coupon: This is the bond coupon level and it is constant over time.

\section{References}

Binsbergen, J., J. Graham and J. Yang. 2010. The cost of debt. Journal of Finance 65(6): 2089-2136.

Fama, E. F. and K. R. French. 1993. Common risk factors in the returns on stocks and bonds. Journal of Financial Economics 33(1): 3-56.

Graham, J. 2000. How big are the tax benefits of debt? Journal of Finance 55 (5): 1901-1941. 


\section{Descriptive statistics}

This table shows descriptive statistics of the explanatory variables described before. The first panel relates to state variables, which are in aggregate terms and, therefore, the descriptive statistics refer to the time dimension. The second panel refers to variables that also have cross-sectional scope and the statistics are applied to both the time dimension for each individual and cross-sectionally across all individuals. The only exceptions are Coupon and Cov, which are constant in time, and then statistics refer only to the cross-sectional variation.

\begin{tabular}{l|ccccccc}
\hline \multicolumn{7}{c}{ State Variables } \\
\hline & Mean & $\begin{array}{c}\text { Std. } \\
\text { Dev. }\end{array}$ & Skewness & Kurtosis & 1st Quartile & Median & 3rd Quartile \\
\hline$\Delta \mathrm{c}$ & 0.001 & 0.002 & -0.218 & 3.029 & 0.000 & 0.002 & 0.003 \\
$\sigma_{\mathrm{c}}$ & 0.002 & 0.001 & 1.253 & 3.918 & 0.002 & 0.002 & 0.003 \\
Default & 0.026 & 0.011 & 1.427 & 4.544 & 0.018 & 0.023 & 0.032 \\
$\Delta$ GDP & 0.001 & 0.006 & -0.644 & 4.279 & -0.002 & 0.001 & 0.005 \\
$\Delta$ IPI & 0.000 & 0.008 & -1.854 & 9.278 & -0.003 & 0.001 & 0.005 \\
Tbill & 0.022 & 0.017 & 0.406 & 1.739 & 0.009 & 0.017 & 0.039 \\
Term & 0.019 & 0.013 & -0.361 & 1.686 & 0.006 & 0.023 & 0.030 \\
VIX & 0.213 & 0.102 & 1.540 & 5.410 & 0.133 & 0.179 & 0.260 \\
\hline
\end{tabular}

\begin{tabular}{l|ccccccc}
\hline \multicolumn{7}{c}{ Firm Issue Variables } \\
\hline & Mean & Dev. & Skewness & Kurtosis & 1st Quartile & Median & 3rd Quartile \\
\hline$\beta$ & 0.931 & 0.319 & 0.485 & 3.628 & 0.715 & 0.899 & 1.107 \\
$\beta_{\mathrm{FF}}$ & 0.962 & 0.323 & 0.391 & 3.857 & 0.759 & 0.937 & 1.145 \\
$\beta^{\mathrm{UN} 1}$ & 0.728 & 0.241 & 0.392 & 3.373 & 0.562 & 0.710 & 0.875 \\
$\beta^{\mathrm{UN} 2}$ & 0.720 & 0.267 & 0.407 & 3.675 & 0.547 & 0.697 & 0.862 \\
$\beta^{\mathrm{UN} 3}$ & 0.734 & 0.239 & 0.366 & 3.339 & 0.568 & 0.717 & 0.882 \\
$\beta^{\mathrm{UN} 1}$ & 0.761 & 0.259 & 0.273 & 3.587 & 0.592 & 0.745 & 0.918 \\
$\beta^{\mathrm{UN} 2}{ }_{\mathrm{FF}}$ & 0.753 & 0.284 & 0.318 & 3.868 & 0.577 & 0.732 & 0.909 \\
$\beta^{\mathrm{UN} 3}$ & 0.768 & 0.259 & 0.261 & 3.537 & 0.601 & 0.752 & 0.927 \\
$\sigma_{\mathrm{FF}}^{\mathrm{Tot}}$ & 1.882 & 1.146 & 1.863 & 6.434 & 1.164 & 1.454 & 2.141 \\
$\sigma^{\mathrm{Id}}$ & 1.438 & 0.754 & 1.548 & 5.324 & 0.959 & 1.168 & 1.647 \\
$\sigma^{\mathrm{Id}}{ }_{\mathrm{FF}}$ & 1.365 & 0.691 & 1.540 & 5.326 & 0.919 & 1.122 & 1.570 \\
Lev & 0.567 & 0.393 & 1.265 & 5.113 & 0.343 & 0.432 & 0.650 \\
Default Prob & 0.302 & 0.559 & 2.018 & 7.749 & 0.029 & 0.071 & 0.240 \\
Cov & 4.417 & 2.265 & -0.881 & 2.594 & 3.000 & 5.000 & 6.000 \\
Ami & 0.278 & 0.131 & 1.464 & 5.764 & 0.191 & 0.259 & 0.307 \\
Ami & 0.139 & 0.259 & 4.087 & 25.637 & 0.018 & 0.056 & 0.160 \\
Time & 1924.9 & 690.1 & 0.274 & 1.917 & 1314.6 & 1841.0 & 2515.5 \\
Coupon & 5.614 & 1.414 & -1.047 & 7.321 & 4.900 & 5.700 & 6.500 \\
\hline
\end{tabular}


Table 1: Descriptive Statistics of Bonds Issues

This table shows descriptive statistics about characteristics of our selected bonds in comparison with all bonds in the TRACE database

\begin{tabular}{lcc|cc}
\hline Our Sample & & & \multicolumn{2}{c}{ TRACE } \\
\hline \hline Number of issuers & 72 & & 4544 & \\
Industrial & 55 & $76 \%$ & 2949 & $65 \%$ \\
Finance & 13 & $18 \%$ & 1153 & $25 \%$ \\
Utility & 4 & $6 \%$ & 423 & $9 \%$ \\
& & & & \\
Number of bonds & 467 & & 38830 & \\
$\quad$ Industrial & 253 & $54 \%$ & 10346 & $27 \%$ \\
Finance & 202 & $43 \%$ & 25947 & $67 \%$ \\
$\quad$ Utility & 12 & $3 \%$ & 2269 & $6 \%$ \\
\hline Mean & $\underline{\text { Std. Dev. }}$ & Mean & $\underline{\text { Std. Dev. }}$ \\
Yield & 5.65 & 1.24 & 5.80 & 3.88 \\
Treasury spread & 102.42 & 54.41 & 149.57 & 126.37 \\
Coupon & 5.61 & 1.41 & 6.31 & 2.03 \\
Maturity & 12.07 & 8.48 & 12.51 & 9.59 \\
Average Issues per firm: & 6.49 & 8.44 & 8.55 & 60.97 \\
Industrial & 4.60 & 3.90 & 3.51 & 12.73 \\
Finance & 15.54 & 15.59 & 22.50 & 118.09 \\
Utility & 3.00 & 2.16 & 5.36 & 6.62 \\
\hline
\end{tabular}

This article has been accepted for publication and undergone full peer review but has not been through the copyediting, typesetting, pagination and proofreading process, which may lead to differences between this version and the Version of Record. Please cite this article as doi: 10.1111/jbfa.12114. 
Table 2: Descriptive Statistics on the Cross-Sectional Distribution of the Correlations

This table shows descriptive statistics for the three quartiles of the distribution and the first-order serial correlation of the 467 bond-stock estimated correlations. The term SMPL refers to a sample correlation that is computed with a window of three months of daily past returns, DCC indicates the DCC estimate, and DCCD is a version of the standard DCC estimate that incorporates an adjustment for non-trading days.

\begin{tabular}{lccc|ccc|ccc|ccc}
\hline \multicolumn{5}{c}{} & \multicolumn{3}{c}{ Median } & \multicolumn{3}{c|}{$25^{\text {th }}$ Percentile } & \multicolumn{3}{c|}{$75^{\text {th }}$ Percentile } & \multicolumn{3}{c}{1 Lag Autocorrelation } \\
\hline \hline Mean & SMPL & DCC & DCCD & SMPL & DCC & DCCD & SMPL & DCC & DCCD & SMPL & DCC & DCCD \\
Median & 0.005 & 0.007 & 0.007 & -0.101 & -0.007 & -0.007 & 0.110 & 0.020 & 0.022 & 0.608 & 0.219 & 0.174 \\
Min. & -0.173 & -0.172 & -0.386 & -0.292 & -0.187 & -0.788 & -0.098 & -0.160 & -0.266 & 0.137 & -0.379 & -0.545 \\
Max. & 0.308 & 0.337 & 0.320 & 0.234 & 0.332 & 0.315 & 0.449 & 0.350 & 0.342 & 0.828 & 0.958 & 0.969 \\
Std. Dev. & 0.059 & 0.061 & 0.062 & 0.058 & 0.062 & 0.071 & 0.064 & 0.062 & 0.064 & 0.106 & 0.324 & 0.307 \\
Skewn. & 1.068 & 1.245 & 0.658 & 0.972 & 1.045 & -2.241 & 1.202 & 1.303 & 1.043 & -0.842 & 0.678 & 0.831 \\
Kurtosis & 6.726 & 8.106 & 10.413 & 7.186 & 7.612 & 38.271 & 7.615 & 7.932 & 8.082 & 4.079 & 2.564 & 3.065 \\
\hline
\end{tabular}


Table 3: Panel Estimation-Sample Correlations

The table displays the results of the system GMM two-step estimation of a model with dynamic sample stockbond return correlations as dependent variable and the variables indicated in the left column as explanatory variables. The values in parentheses are the $p$-values associated with the Windmeijer (2005) corrected standard errors. Five to seven lags of the dependent variables are used as instruments. Explanatory variables are assumed to be strictly exogenous. The number of instruments is reported at the top of each column, the Arellano-Bond test for residual autocorrelation is reported toward the bottom for orders 1 to 5, and the Hansen and Sargan tests are in the bottom rows.

\begin{tabular}{|c|c|c|c|c|c|c|c|c|c|c|}
\hline \# Instruments & 337 & 337 & 337 & 337 & 337 & 336 & 336 & 337 & 338 & 337 \\
\hline $\mathrm{q}_{\mathrm{t}-1}$ & $\begin{array}{r}0.704 \\
(0.000)\end{array}$ & $\begin{array}{r}0.703 \\
(0.000)\end{array}$ & $\begin{array}{r}0.708 \\
(0.000)\end{array}$ & $\begin{array}{r}0.686 \\
(0.000)\end{array}$ & $\begin{array}{r}0.683 \\
(0.000)\end{array}$ & $\begin{array}{r}0.712 \\
(0.000)\end{array}$ & $\begin{array}{r}0.708 \\
(0.000)\end{array}$ & $\begin{array}{r}0.711 \\
(0.000)\end{array}$ & $\begin{array}{r}0.696 \\
(0.000)\end{array}$ & $\begin{array}{r}0.699 \\
(0.000)\end{array}$ \\
\hline$\sigma_{\mathrm{c}}$ & $\begin{array}{l}-7.302 \\
(0.005)\end{array}$ & $\begin{array}{l}-5.749 \\
(0.127)\end{array}$ & & $\begin{array}{r}-0.510 \\
(0.850)\end{array}$ & & $\begin{array}{l}-5.749 \\
(0.025)\end{array}$ & $\begin{array}{l}-5.525 \\
(0.152)\end{array}$ & & $\begin{array}{r}-6.998 \\
(0.007)\end{array}$ & $\begin{array}{r}-5.553 \\
(0.137)\end{array}$ \\
\hline VIX & $\begin{array}{r}1.822 \\
(0.177)\end{array}$ & & $\begin{array}{r}2.235 \\
(0.114)\end{array}$ & & $\begin{array}{r}12.79 \\
(0.000)\end{array}$ & $\begin{array}{r}5.783 \\
(0.000)\end{array}$ & & $\begin{array}{r}5.957 \\
(0.000)\end{array}$ & $\begin{array}{r}1.921 \\
(0.149)\end{array}$ & \\
\hline Term & & $\begin{array}{l}-2.151 \\
(0.838)\end{array}$ & $\begin{array}{r}-19.36 \\
(0.010)\end{array}$ & & & & $\begin{array}{r}19.99 \\
(0.050)\end{array}$ & $\begin{array}{l}-15.33 \\
(0.042)\end{array}$ & & $\begin{array}{l}-0.986 \\
(0.925)\end{array}$ \\
\hline Default & & & & $\begin{array}{r}-6.268 \\
(0.000)\end{array}$ & $\begin{array}{c}-16.48 \\
(0.000)\end{array}$ & & & & & \\
\hline$\sigma^{\text {Id }}$ & $\begin{array}{r}0.610 \\
(0.000)\end{array}$ & $\begin{array}{r}0.697 \\
(0.000)\end{array}$ & $\begin{array}{r}0.595 \\
(0.001)\end{array}$ & $\begin{array}{r}1.088 \\
(0.000)\end{array}$ & $\begin{array}{r}1.051 \\
(0.000)\end{array}$ & & & & $\begin{array}{r}0.618 \\
(0.000)\end{array}$ & $\begin{array}{r}0.621 \\
(0.000)\end{array}$ \\
\hline Lev & $\begin{array}{c}-0.055 \\
(0.159)\end{array}$ & $\begin{array}{l}-0.062 \\
(0.099)\end{array}$ & $\begin{array}{r}-0.055 \\
(0.156)\end{array}$ & $\begin{array}{l}-0.088 \\
(0.024)\end{array}$ & $\begin{array}{l}-0.073 \\
(0.058)\end{array}$ & & & & & \\
\hline Def. Prob & & & & & & $\begin{array}{r}0.005 \\
(0.861)\end{array}$ & $\begin{array}{r}0.034 \\
(0.247)\end{array}$ & $\begin{array}{r}0.012 \\
(0.661)\end{array}$ & $\begin{array}{r}-0.082 \\
(0.011)\end{array}$ & \\
\hline$\beta^{\mathrm{UN}}$ & & & & & & & & $\begin{array}{r}-0.670 \\
(0.065) \\
\end{array}$ & $\begin{array}{r}-0.614 \\
(0.084) \\
\end{array}$ & $\begin{array}{l}-0.675 \\
(0.055) \\
\end{array}$ \\
\hline Time & $\begin{array}{c}-0.029 \\
(0.279)\end{array}$ & $\begin{array}{l}-0.028 \\
(0.290)\end{array}$ & $\begin{array}{c}-0.031 \\
(0.251)\end{array}$ & $\begin{array}{r}-0.027 \\
(0.344)\end{array}$ & $\begin{array}{l}-0.028 \\
(0.318)\end{array}$ & $\begin{array}{l}-0.026 \\
(0.317)\end{array}$ & $\begin{array}{l}-0.018 \\
(0.506)\end{array}$ & $\begin{array}{l}-0.025 \\
(0.349)\end{array}$ & $\begin{array}{l}-0.025 \\
(0.360)\end{array}$ & $\begin{array}{c}-0.020 \\
(0.459)\end{array}$ \\
\hline Ind1 & $\begin{array}{r}-1.347 \\
(0.003)\end{array}$ & $\begin{array}{l}-1.376 \\
(0.002)\end{array}$ & $\begin{array}{r}-1.344 \\
(0.003)\end{array}$ & $\begin{array}{r}-1.567 \\
(0.001)\end{array}$ & $\begin{array}{r}-1.560 \\
(0.001)\end{array}$ & $\begin{array}{l}-1.309 \\
(0.005)\end{array}$ & $\begin{array}{l}-1.434 \\
(0.002)\end{array}$ & $\begin{array}{l}-1.355 \\
(0.008)\end{array}$ & $\begin{array}{r}-1.389 \\
(0.004)\end{array}$ & $\begin{array}{c}-1.412 \\
(0.003)\end{array}$ \\
\hline Ind & $\begin{array}{r}-0.453 \\
(0.291)\end{array}$ & $\begin{array}{l}-0.510 \\
(0.230)\end{array}$ & $\begin{array}{c}-0.459 \\
(0.284)\end{array}$ & $\begin{array}{r}-0.783 \\
(0.079)\end{array}$ & $\begin{array}{c}-0.771 \\
(0.081)\end{array}$ & $\begin{array}{l}-0.269 \\
(0.526)\end{array}$ & $\begin{array}{l}-0.407 \\
(0.340)\end{array}$ & $\begin{array}{l}-0.462 \\
(0.347)\end{array}$ & $\begin{array}{r}-0.696 \\
(0.140)\end{array}$ & $\begin{array}{r}-0.830 \\
(0.075)\end{array}$ \\
\hline Con & $\begin{array}{r}1.309 \\
(0.040) \\
\end{array}$ & $\begin{array}{r}1.326 \\
(0.074) \\
\end{array}$ & $\begin{array}{r}0.144 \\
(0.745) \\
\end{array}$ & $\begin{array}{r}1.522 \\
(0.019) \\
\end{array}$ & $\begin{array}{r}1.446 \\
(0.002) \\
\end{array}$ & $\begin{array}{r}0.955 \\
(0.137) \\
\end{array}$ & $\begin{array}{r}1.856 \\
(0.019) \\
\end{array}$ & $\begin{array}{r}0.588 \\
(0.363) \\
\end{array}$ & $\begin{array}{r}1.692 \\
(0.024) \\
\end{array}$ & $\begin{array}{r}1.860 \\
(0.025) \\
\end{array}$ \\
\hline $\begin{array}{l}\text { Are-Bond } \\
\text { AR(1) Test }\end{array}$ & $\begin{array}{r}-12.55 \\
(0.000) \\
\end{array}$ & $\begin{array}{r}-12.57 \\
(0.000) \\
\end{array}$ & $\begin{array}{r}-12.60 \\
(0.000) \\
\end{array}$ & $\begin{array}{r}-12.28 \\
(0.000) \\
\end{array}$ & $\begin{array}{r}-12.33 \\
(0.000)\end{array}$ & $\begin{array}{l}-12.82 \\
(0.000)\end{array}$ & $\begin{array}{l}-12.78 \\
(0.000) \\
\end{array}$ & $\begin{array}{r}-12.66 \\
(0.000) \\
\end{array}$ & $\begin{array}{c}-12.32 \\
(0.000)\end{array}$ & $\begin{array}{l}-12.45 \\
(0.000)\end{array}$ \\
\hline $\begin{array}{l}\text { Are-Bond } \\
\text { AR(2) Test }\end{array}$ & $\begin{array}{r}13.80 \\
(0.000) \\
\end{array}$ & $\begin{array}{r}13.78 \\
(0.000) \\
\end{array}$ & $\begin{array}{r}13.81 \\
(0.000) \\
\end{array}$ & $\begin{array}{r}13.73 \\
(0.000) \\
\end{array}$ & $\begin{array}{r}13.81 \\
(0.000) \\
\end{array}$ & $\begin{array}{r}13.87 \\
(0.000) \\
\end{array}$ & $\begin{array}{r}13.83 \\
(0.000) \\
\end{array}$ & $\begin{array}{r}13.86 \\
(0.000) \\
\end{array}$ & $\begin{array}{r}13.76 \\
(0.000) \\
\end{array}$ & $\begin{array}{r}13.77 \\
(0.000) \\
\end{array}$ \\
\hline $\begin{array}{l}\text { Are-Bond } \\
\text { AR(3) Test }\end{array}$ & $\begin{array}{c}-16.85 \\
(0.000)\end{array}$ & $\begin{array}{l}-16.86 \\
(0.000)\end{array}$ & $\begin{array}{r}-16.85 \\
(0.000)\end{array}$ & $\begin{array}{c}-16.83 \\
(0.000)\end{array}$ & $\begin{array}{c}-16.81 \\
(0.000)\end{array}$ & $\begin{array}{l}-16.88 \\
(0.000)\end{array}$ & $\begin{array}{l}-16.91 \\
(0.000)\end{array}$ & $\begin{array}{r}-16.86 \\
(0.000)\end{array}$ & $\begin{array}{c}-16.81 \\
(0.000)\end{array}$ & $\begin{array}{c}-16.85 \\
(0.000)\end{array}$ \\
\hline $\begin{array}{l}\text { Are-Bond } \\
\text { AR(4) Test }\end{array}$ & $\begin{array}{r}9.949 \\
(0.000) \\
\end{array}$ & $\begin{array}{r}9.968 \\
(0.000) \\
\end{array}$ & $\begin{array}{r}9.992 \\
(0.000)\end{array}$ & $\begin{array}{r}9.762 \\
(0.000)\end{array}$ & $\begin{array}{r}9.723 \\
(0.000)\end{array}$ & $\begin{array}{r}10.04 \\
(0.000)\end{array}$ & $\begin{array}{r}10.04 \\
(0.000)\end{array}$ & $\begin{array}{r}9.953 \\
(0.000)\end{array}$ & $\begin{array}{r}9.794 \\
(0.000)\end{array}$ & $\begin{array}{r}9.888 \\
(0.000)\end{array}$ \\
\hline $\begin{array}{l}\text { Are-Bond } \\
\text { AR(5) Test }\end{array}$ & $\begin{array}{r}0.492 \\
(0.622)\end{array}$ & $\begin{array}{r}0.507 \\
(0.612)\end{array}$ & $\begin{array}{r}0.499 \\
(0.618)\end{array}$ & $\begin{array}{r}0.509 \\
(0.611)\end{array}$ & $\begin{array}{r}0.420 \\
(0.674)\end{array}$ & $\begin{array}{r}0.476 \\
(0.634)\end{array}$ & $\begin{array}{r}0.506 \\
(0.613)\end{array}$ & $\begin{array}{r}0.497 \\
(0.620)\end{array}$ & $\begin{array}{r}0.525 \\
(0.600)\end{array}$ & $\begin{array}{r}0.522 \\
(0.602)\end{array}$ \\
\hline Sargan Test & $\begin{array}{r}575.7 \\
(0.000)\end{array}$ & $\begin{array}{r}575.1 \\
(0.000)\end{array}$ & $\begin{array}{r}574.9 \\
(0.000)\end{array}$ & $\begin{array}{r}576.5 \\
(0.000)\end{array}$ & $\begin{array}{r}570.7 \\
(0.000)\end{array}$ & $\begin{array}{r}573.6 \\
(0.000)\end{array}$ & $\begin{array}{r}573.2 \\
(0.000)\end{array}$ & $\begin{array}{r}574.7 \\
(0.000)\end{array}$ & $\begin{array}{r}578.3 \\
(0.000)\end{array}$ & $\begin{array}{r}575.8 \\
(0.000)\end{array}$ \\
\hline Hans & $\begin{array}{r}337.0 \\
(0.354)\end{array}$ & $\begin{array}{r}336.3 \\
(0.364)\end{array}$ & $\begin{array}{r}337.7 \\
(0.345)\end{array}$ & $\begin{array}{r}335.6 \\
(0.375)\end{array}$ & $\begin{array}{r}335.9 \\
(0.371)\end{array}$ & $\begin{array}{r}339.1 \\
(0.324)\end{array}$ & $\begin{array}{r}338.0 \\
(0.341)\end{array}$ & $\begin{array}{r}339.0 \\
(0.326)\end{array}$ & $\begin{array}{r}334.8 \\
(0.386)\end{array}$ & $\begin{array}{r}335.9 \\
(0.370)\end{array}$ \\
\hline
\end{tabular}




\section{Table 4: Panel Estimation-DCC Estimates}

This table displays the results of the system GMM two-step estimation of a model with dynamic conditional stock-bond return correlations as dependent variable and the variables indicated in the left column as explanatory variables. The values in parentheses are the $p$-values associated with Windmeijer (2005) corrected standard errors. The second lags of the dependent variables are used as instruments. Explanatory variables are assumed to be strictly exogenous. The number of instruments is reported at the top of each column, the Arellano-Bond test for residual autocorrelation is reported toward the bottom for orders 1 and 2, and the Hansen and Sargan tests are in the bottom rows.

\begin{tabular}{|c|c|c|c|c|c|c|c|c|c|c|}
\hline \# Instruments & 184 & 184 & 184 & 184 & 184 & 183 & 183 & 184 & 185 & 184 \\
\hline \multirow[t]{2}{*}{$\mathrm{q}_{\mathrm{t}-1}$} & 0.473 & 0.473 & 0.476 & 0.472 & 0.471 & 0.481 & 0.487 & 0.484 & 0.468 & 0.470 \\
\hline & $(0.000)$ & $(0.000)$ & $(0.000)$ & $(0.000)$ & $(0.000)$ & $(0.000)$ & $(0.000)$ & $(0.000)$ & $(0.000)$ & $(0.000)$ \\
\hline \multirow[t]{2}{*}{$\sigma_{\mathrm{c}}$} & -7.327 & -7.849 & & -6.617 & & -6.736 & -7.029 & & -6.921 & -7.227 \\
\hline & $(0.000)$ & $(0.000)$ & & $(0.000)$ & & $(0.000)$ & $(0.000)$ & & $(0.000)$ & $(0.000)$ \\
\hline \multirow[t]{2}{*}{ VIX } & 0.0741 & & 0.125 & & 1.509 & 1.602 & & 1.575 & -0.318 & \\
\hline & $(0.870)$ & & $(0.788)$ & & $(0.002)$ & $(0.000)$ & & $(0.000)$ & $(0.489)$ & \\
\hline \multirow[t]{2}{*}{ Term } & & 2.416 & -12.16 & & & & 8.340 & -10.42 & & 0.0858 \\
\hline & & $(0.412)$ & $(0.000)$ & & & & $(0.004)$ & (0.003) & & $(0.977)$ \\
\hline \multirow[t]{2}{*}{ Default } & & & & -0.821 & -3.209 & & & & & \\
\hline & & & & $(0.154)$ & $(0.000)$ & & & & & \\
\hline \multirow[t]{2}{*}{$\sigma^{\text {Id }}$} & 0.156 & 0.155 & 0.138 & 0.211 & 0.236 & & & & 0.321 & 0.282 \\
\hline & $(0.010)$ & $(0.005)$ & $(0.020)$ & $(0.003)$ & $(0.001)$ & & & & $(0.000)$ & $(0.000)$ \\
\hline \multirow[t]{2}{*}{ Lev } & 0.109 & 0.109 & 0.108 & 0.107 & 0.107 & & & & & \\
\hline & $(0.000)$ & $(0.000)$ & $(0.000)$ & $(0.000)$ & $(0.000)$ & & & & & \\
\hline \multirow[t]{2}{*}{ Def. Prob. } & & & & & & 0.001 & 0.003 & 0.002 & -0.0331 & \\
\hline & & & & & & $(0.971)$ & $(0.870)$ & (0.908) & $(0.063)$ & \\
\hline \multirow[t]{2}{*}{$\beta^{\mathrm{UN}}$} & & & & & & & & -0.988 & -1.013 & -1.018 \\
\hline & & & & & & & & $(0.000)$ & $(0.000)$ & $(0.000)$ \\
\hline \multirow[t]{2}{*}{ Time } & 0.0525 & 0.0542 & 0.0496 & 0.0493 & 0.0436 & 0.0375 & 0.0380 & 0.0423 & 0.0488 & 0.0496 \\
\hline & $(0.174)$ & $(0.160)$ & $(0.203)$ & $(0.202)$ & $(0.277)$ & $(0.316)$ & $(0.299)$ & $(0.283)$ & $(0.219)$ & $(0.210)$ \\
\hline \multirow[t]{2}{*}{ Ind1 } & -2.888 & -2.892 & -2.922 & -2.903 & -2.999 & -3.056 & -3.089 & -2.689 & -2.813 & -2.810 \\
\hline & $(0.000)$ & $(0.000)$ & $(0.000)$ & $(0.000)$ & $(0.000)$ & $(0.000)$ & $(0.000)$ & $(0.000)$ & $(0.000)$ & $(0.000)$ \\
\hline \multirow[t]{2}{*}{ Ind2 } & -1.526 & -1.526 & -1.565 & -1.557 & -1.665 & -1.318 & -1.369 & -1.196 & -1.369 & -1.394 \\
\hline & $(0.005)$ & $(0.005)$ & $(0.003)$ & $(0.004)$ & $(0.002)$ & $(0.016)$ & $(0.016)$ & $(0.052)$ & $(0.024)$ & $(0.020)$ \\
\hline \multirow[t]{2}{*}{ Constant } & 3.289 & 3.360 & 2.137 & 3.324 & 2.449 & 3.328 & 3.571 & 2.583 & 3.787 & 3.837 \\
\hline & $(0.000)$ & $(0.000)$ & $(0.000)$ & $(0.000)$ & $(0.000)$ & $(0.000)$ & $(0.000)$ & $(0.000)$ & $(0.000)$ & $(0.000)$ \\
\hline \multirow{2}{*}{$\begin{array}{l}\text { Are-Bond } \\
\text { AR(1) Test }\end{array}$} & -10.10 & -10.11 & -10.07 & -10.10 & -10.09 & -10.13 & -10.18 & -10.12 & -10.01 & -10.02 \\
\hline & $(0.000)$ & $(0.000)$ & $(0.000)$ & $(0.000)$ & $(0.000)$ & $(0.000)$ & $(0.000)$ & $(0.000)$ & $(0.000)$ & $(0.000)$ \\
\hline \multirow{2}{*}{$\begin{array}{l}\text { Are-Bond } \\
\text { AR(2) Test }\end{array}$} & -1.294 & -1.295 & -1.265 & -1.298 & -1.261 & -1.203 & -1.156 & -1.225 & -1.436 & -1.393 \\
\hline & $(0.196)$ & $(0.195)$ & $(0.206)$ & $(0.194)$ & $(0.207)$ & $(0.229)$ & $(0.248)$ & $(0.221)$ & $(0.151)$ & $(0.164)$ \\
\hline \multirow[t]{2}{*}{ Sargan Test } & 602.1 & 601.0 & 608.8 & 600.9 & $\bar{~} 597.1$ & 596.4 & 602.8 & 602.8 & 623.2 & 619.7 \\
\hline & $(0.000)$ & $(0.000)$ & $(0.000)$ & $(0.000)$ & $(0.000)$ & $(0.000)$ & $(0.000)$ & $(0.000)$ & $(0.000)$ & $(0.000)$ \\
\hline \multirow[t]{2}{*}{ Hansen Test } & 194.5 & 195.2 & 197.2 & 193.9 & 197.3 & 197.5 & 200.0 & 200.8 & 194.4 & 195.0 \\
\hline & (0.149) & $(0.141)$ & $(0.120)$ & $(0.156)$ & $(0.119)$ & $(0.117)$ & $(0.095)$ & $(0.088)$ & $(0.150)$ & $(0.143)$ \\
\hline
\end{tabular}


Table 5: Panel Estimation-Non-Trading Adjusted DCC Estimates

This table displays the results of the system GMM two-step estimation of a model with non-trading adjusted dynamic conditional stock-bond return correlations as dependent variables and the variables indicated in the left column as explanatory variables. The values in parentheses are the $p$-values associated with Windmeijer (2005) corrected standard errors. The second lags of the dependent variable are used as instruments. The explanatory variables are assumed to be strictly exogenous. The number of instruments is reported at the top of each column, the Arellano-Bond test for residual autocorrelation is reported toward the bottom for orders 1 and 2, and the Hansen and Sargan tests are in the bottom rows.

\begin{tabular}{|c|c|c|c|c|c|c|c|c|c|c|}
\hline \# Instruments & 184 & 184 & 184 & 184 & 184 & 183 & 183 & 184 & 185 & 184 \\
\hline $\mathrm{q}_{\mathrm{t}-1}$ & $\begin{array}{c}0.482 \\
(0.000)\end{array}$ & $\begin{array}{c}0.539 \\
(0.000)\end{array}$ & $\begin{array}{c}0.537 \\
(0.000)\end{array}$ & $\begin{array}{c}0.539 \\
(0.000)\end{array}$ & $\begin{array}{c}0.531 \\
(0.000)\end{array}$ & $\begin{array}{c}0.543 \\
(0.000)\end{array}$ & $\begin{array}{c}0.547 \\
(0.000)\end{array}$ & $\begin{array}{c}0.543 \\
(0.000)\end{array}$ & $\begin{array}{c}0.533 \\
(0.000)\end{array}$ & $\begin{array}{c}0.532 \\
(0.000)\end{array}$ \\
\hline$\sigma_{\mathrm{c}}$ & $\begin{array}{l}-7.571 \\
(0.000)\end{array}$ & $\begin{array}{l}-6.405 \\
(0.003)\end{array}$ & & $\begin{array}{l}-5.472 \\
(0.007)\end{array}$ & & $\begin{array}{l}-6.440 \\
(0.002)\end{array}$ & $\begin{array}{l}-5.697 \\
(0.004)\end{array}$ & & $\begin{array}{l}-6.209 \\
(0.004)\end{array}$ & $\begin{array}{l}-5.655 \\
(0.006)\end{array}$ \\
\hline VIX & $\begin{array}{l}-0.0157 \\
(0.976)\end{array}$ & & $\begin{array}{l}0.0814 \\
(0.871)\end{array}$ & & $\begin{array}{c}1.773 \\
(0.010)\end{array}$ & $\begin{array}{c}1.296 \\
(0.016)\end{array}$ & & $\begin{array}{c}1.362 \\
(0.014)\end{array}$ & $\begin{array}{l}-0.807 \\
(0.076)\end{array}$ & \\
\hline Term & & $\begin{array}{l}-1.008 \\
(0.716)\end{array}$ & $\begin{array}{l}-14.41 \\
(0.003)\end{array}$ & & & & $\begin{array}{c}2.433 \\
(0.395)\end{array}$ & $\begin{array}{l}-13.50 \\
(0.004)\end{array}$ & & $\begin{array}{l}-4.594 \\
(0.103)\end{array}$ \\
\hline Default & & & & $\begin{array}{l}-1.225 \\
(0.017)\end{array}$ & $\begin{array}{l}-3.530 \\
(0.000)\end{array}$ & & & & & \\
\hline$\sigma^{\mathrm{Id}}$ & $\begin{array}{c}0.158 \\
(0.012)\end{array}$ & $\begin{array}{c}0.109 \\
(0.045)\end{array}$ & $\begin{array}{c}0.111 \\
(0.046)\end{array}$ & $\begin{array}{c}0.181 \\
(0.007)\end{array}$ & $\begin{array}{c}0.200 \\
(0.005)\end{array}$ & & & & $\begin{array}{c}0.313 \\
(0.000)\end{array}$ & $\begin{array}{c}0.276 \\
(0.000)\end{array}$ \\
\hline Lev & $\begin{array}{c}0.126 \\
(0.000)\end{array}$ & $\begin{array}{c}0.124 \\
(0.000)\end{array}$ & $\begin{array}{c}0.124 \\
(0.000)\end{array}$ & $\begin{array}{c}0.122 \\
(0.000)\end{array}$ & $\begin{array}{c}0.125 \\
(0.000)\end{array}$ & & & & & \\
\hline Def. Prob & & & & & & $\begin{array}{l}0.0198 \\
(0.196)\end{array}$ & $\begin{array}{l}0.0275 \\
(0.097)\end{array}$ & $\begin{array}{l}0.0305 \\
(0.060)\end{array}$ & $\begin{array}{l}-0.0114 \\
(0.465)\end{array}$ & \\
\hline$\beta^{\mathrm{UN}}$ & & & & & & & & $\begin{array}{l}-1.213 \\
(0.000) \\
\end{array}$ & $\begin{array}{l}-1.244 \\
(0.000) \\
\end{array}$ & $\begin{array}{l}-1.239 \\
(0.000) \\
\end{array}$ \\
\hline Time & $\begin{array}{l}0.0843 \\
(0.035)\end{array}$ & $\begin{array}{l}0.0926 \\
(0.007)\end{array}$ & $\begin{array}{l}0.0913 \\
(0.008)\end{array}$ & $\begin{array}{l}0.0904 \\
(0.009)\end{array}$ & $\begin{array}{l}0.0918 \\
(0.008)\end{array}$ & $\begin{array}{l}0.0700 \\
(0.025)\end{array}$ & $\begin{array}{l}0.0713 \\
(0.023)\end{array}$ & $\begin{array}{l}0.0768 \\
(0.015)\end{array}$ & $\begin{array}{l}0.0810 \\
(0.017)\end{array}$ & $\begin{array}{l}0.0802 \\
(0.019)\end{array}$ \\
\hline Ind1 & $\begin{array}{l}-3.224 \\
(0.000) \\
\end{array}$ & $\begin{array}{l}-2.888 \\
(0.000) \\
\end{array}$ & $\begin{array}{l}-2.826 \\
(0.000) \\
\end{array}$ & $\begin{array}{l}-2.892 \\
(0.000) \\
\end{array}$ & $\begin{array}{l}-2.894 \\
(0.000) \\
\end{array}$ & $\begin{array}{l}-2.976 \\
(0.000) \\
\end{array}$ & $\begin{array}{l}-2.972 \\
(0.000) \\
\end{array}$ & $\begin{array}{l}-2.935 \\
(0.000) \\
\end{array}$ & $\begin{array}{l}-3.014 \\
(0.000) \\
\end{array}$ & $\begin{array}{l}-2.979 \\
(0.000) \\
\end{array}$ \\
\hline Ind2 & $\begin{array}{l}-1.635 \\
(0.007)\end{array}$ & $\begin{array}{l}-1.457 \\
(0.023)\end{array}$ & $\begin{array}{l}-1.379 \\
(0.032)\end{array}$ & $\begin{array}{l}-1.484 \\
(0.021)\end{array}$ & $\begin{array}{l}-1.470 \\
(0.022)\end{array}$ & $\begin{array}{l}-1.111 \\
(0.075)\end{array}$ & $\begin{array}{l}-1.133 \\
(0.064)\end{array}$ & $\begin{array}{l}-1.308 \\
(0.049)\end{array}$ & $\begin{array}{l}-1.471 \\
(0.030)\end{array}$ & $\begin{array}{l}-1.434 \\
(0.033)\end{array}$ \\
\hline Constant & $\begin{array}{c}3.533 \\
(0.000)\end{array}$ & $\begin{array}{c}3.058 \\
(0.002)\end{array}$ & $\begin{array}{c}1.933 \\
(0.007)\end{array}$ & $\begin{array}{c}3.088 \\
(0.001)\end{array}$ & $\begin{array}{c}2.187 \\
(0.003)\end{array}$ & $\begin{array}{c}3.124 \\
(0.001)\end{array}$ & $\begin{array}{c}3.183 \\
(0.001)\end{array}$ & $\begin{array}{c}2.900 \\
(0.000)\end{array}$ & $\begin{array}{c}4.001 \\
(0.000)\end{array}$ & $\begin{array}{c}3.818 \\
(0.000)\end{array}$ \\
\hline $\begin{array}{l}\text { Are-Bond } \\
\text { AR(1) Test }\end{array}$ & $\begin{array}{l}-9.831 \\
(0.000) \\
\end{array}$ & $\begin{array}{l}-6.405 \\
(0.000)\end{array}$ & $\begin{array}{l}-6.507 \\
(0.000)\end{array}$ & $\begin{array}{l}-6.397 \\
(0.000)\end{array}$ & $\begin{array}{l}-6.389 \\
(0.000)\end{array}$ & $\begin{array}{l}-6.491 \\
(0.000)\end{array}$ & $\begin{array}{l}-6.619 \\
(0.000)\end{array}$ & $\begin{array}{l}-6.518 \\
(0.000)\end{array}$ & $\begin{array}{l}-6.227 \\
(0.000)\end{array}$ & $\begin{array}{l}-6.231 \\
(0.000)\end{array}$ \\
\hline $\begin{array}{l}\text { Are-Bond } \\
\text { AR(2) Test }\end{array}$ & $\begin{array}{c}0.151 \\
(0.880) \\
\end{array}$ & $\begin{array}{c}0.465 \\
(0.642)\end{array}$ & $\begin{array}{c}0.459 \\
(0.646)\end{array}$ & $\begin{array}{c}0.469 \\
(0.639) \\
\end{array}$ & $\begin{array}{c}0.457 \\
(0.648) \\
\end{array}$ & $\begin{array}{c}0.533 \\
(0.594) \\
\end{array}$ & $\begin{array}{c}0.565 \\
(0.572) \\
\end{array}$ & $\begin{array}{c}0.490 \\
(0.624)\end{array}$ & $\begin{array}{c}0.363 \\
(0.717) \\
\end{array}$ & $\begin{array}{c}0.367 \\
(0.714)\end{array}$ \\
\hline Sargan Test & $\begin{array}{c}546.2 \\
(0.000) \\
\end{array}$ & $\begin{array}{l}1254.8 \\
(0.000)\end{array}$ & $\begin{array}{l}1256.6 \\
(0.000)\end{array}$ & $\begin{array}{l}1252.6 \\
(0.000)\end{array}$ & $\begin{array}{l}1242.3 \\
(0.000)\end{array}$ & $\begin{array}{l}1279.8 \\
(0.000)\end{array}$ & $\begin{array}{l}1278.8 \\
(0.000)\end{array}$ & $\begin{array}{l}1280.8 \\
(0.000)\end{array}$ & $\begin{array}{l}1268.8 \\
(0.000)\end{array}$ & $\begin{array}{l}1268.9 \\
(0.000)\end{array}$ \\
\hline Hansen Test & $\begin{array}{c}192.3 \\
(0.176)\end{array}$ & $\begin{array}{c}194.0 \\
(0.154)\end{array}$ & $\begin{array}{c}193.7 \\
(0.158)\end{array}$ & $\begin{array}{c}194.5 \\
(0.149)\end{array}$ & $\begin{array}{c}192.2 \\
(0.177)\end{array}$ & $\begin{array}{c}190.8 \\
(0.197)\end{array}$ & $\begin{array}{c}190.0 \\
(0.208)\end{array}$ & $\begin{array}{c}192.9 \\
(0.168)\end{array}$ & $\begin{array}{c}189.3 \\
(0.217)\end{array}$ & $\begin{array}{c}188.4 \\
(0.231)\end{array}$ \\
\hline
\end{tabular}


Table 6: Fama-MacBeth Estimation

This table displays the results from the cross-sectional regression of 467 correlations on the variables indicated in the first column. The Fama-MacBeth estimation is applied to each of the 90 months between July 2002 and December 2009. The $p$-values for individual significance are reported in parentheses. The last row provides a pseudo- $R$-squared value computed with the sum of the 90 residual sums and the 90 total sums, SMPL refers to a sample correlation that is computed with a window of the past three months of daily returns, DCC denotes the correlations estimated by standard DCC methods, while DCCD refers to estimations that include a non-trading adjustment in the specification of the variance and the correlation.

\begin{tabular}{|c|c|c|c|c|c|c|c|c|c|c|c|c|}
\hline & \multicolumn{4}{|c|}{ SMPL } & \multicolumn{4}{|c|}{ DCC } & \multicolumn{4}{|c|}{ DCCD } \\
\hline $\begin{array}{c}\text { Const } \\
.\end{array}$ & $\begin{array}{c}0.647 \\
(0.618\end{array}$ & $\begin{array}{c}0.398 \\
(0.768\end{array}$ & $\begin{array}{c}3.318 \\
(0.004\end{array}$ & $\begin{array}{l}-4.119 \\
(0.000\end{array}$ & $\begin{array}{c}1.551 \\
(0.000\end{array}$ & $\begin{array}{c}0.865 \\
(0.025\end{array}$ & $\begin{array}{c}2.577 \\
(0.000\end{array}$ & $\begin{array}{l}-1.669 \\
(0.000\end{array}$ & $\begin{array}{c}1.912 \\
(0.000\end{array}$ & $\begin{array}{c}0.857 \\
(0.098\end{array}$ & $\begin{array}{c}3.117 \\
(0.000\end{array}$ & $\begin{array}{l}-1.992 \\
(0.000\end{array}$ \\
\hline$\sigma^{\mathrm{Id}}$ & $\begin{array}{c}3.057 \\
(0.000\end{array}$ & $\begin{array}{c}2.971 \\
(0.000\end{array}$ & & $\begin{array}{c}2.362 \\
(0.000\end{array}$ & $\begin{array}{c}1.702 \\
(0.000\end{array}$ & $\begin{array}{c}2.150 \\
(0.000\end{array}$ & & $\begin{array}{c}0.701 \\
(0.000 \\
\end{array}$ & $\begin{array}{c}2.216 \\
(0.000 \\
\end{array}$ & $\begin{array}{c}2.627 \\
(0.000\end{array}$ & & $\begin{array}{r}1.075 \\
(0.000 \\
\end{array}$ \\
\hline Lev & $\begin{array}{l}-0.131 \\
(0.373 \\
\end{array}$ & & $\begin{array}{c}0.361 \\
(0.028 \\
\end{array}$ & $\begin{array}{c}0.206 \\
(0.105 \\
\end{array}$ & $\begin{array}{c}0.469 \\
(0.000\end{array}$ & & $\begin{array}{c}0.584 \\
(0.000\end{array}$ & $\begin{array}{c}0.892 \\
(0.000\end{array}$ & $\begin{array}{c}0.512 \\
(0.000 \\
\end{array}$ & & $\begin{array}{c}0.673 \\
(0.000 \\
\end{array}$ & $\begin{array}{c}0.989 \\
(0.000 \\
\end{array}$ \\
\hline $\begin{array}{l}\text { Def. } \\
\text { Prob }\end{array}$ & $\begin{array}{c}6.261 \\
(0.117\end{array}$ & $\begin{array}{c}5.048 \\
(0.034\end{array}$ & $\begin{array}{c}8.707 \\
(0.026\end{array}$ & $\begin{array}{c}8.461 \\
(0.025\end{array}$ & $\begin{array}{c}3.226 \\
(0.076\end{array}$ & $\begin{array}{c}5.164 \\
(0.000\end{array}$ & $\begin{array}{c}7.673 \\
(0.000\end{array}$ & $\begin{array}{c}0.687 \\
(0.575\end{array}$ & $\begin{array}{l}-1.076 \\
(0.535\end{array}$ & $\begin{array}{c}3.094 \\
(0.001\end{array}$ & $\begin{array}{c}4.800 \\
(0.000\end{array}$ & $\begin{array}{l}-2.612 \\
(0.143\end{array}$ \\
\hline$\beta^{\mathrm{UN}}$ & $\begin{array}{l}-2.872 \\
(0.000 \\
\end{array}$ & $\begin{array}{l}-2.968 \\
(0.000 \\
\end{array}$ & $\begin{array}{r}-1.391 \\
(0.013 \\
\end{array}$ & $\begin{array}{l}-2.269 \\
(0.000 \\
\end{array}$ & $\begin{array}{l}-2.162 \\
(0.000 \\
\end{array}$ & $\begin{array}{l}-3.181 \\
(0.000 \\
\end{array}$ & $\begin{array}{r}-1.388 \\
(0.000 \\
\end{array}$ & $\begin{array}{r}-1.668 \\
(0.000 \\
\end{array}$ & $\begin{array}{r}-3.079 \\
(0.000 \\
\end{array}$ & $\begin{array}{r}-3.983 \\
(0.000 \\
\end{array}$ & $\begin{array}{r}-1.999 \\
(0.000 \\
\end{array}$ & $\begin{array}{r}-2.321 \\
(0.000 \\
\end{array}$ \\
\hline Time & $\begin{array}{c}0.133 \\
(0.012 \\
\end{array}$ & $\begin{array}{c}0.125 \\
(0.018 \\
\end{array}$ & $\begin{array}{c}0.150 \\
(0.008 \\
\end{array}$ & $\begin{array}{c}0.140 \\
(0.005 \\
\end{array}$ & $\begin{array}{c}0.192 \\
(0.000 \\
\end{array}$ & $\begin{array}{c}0.183 \\
(0.000 \\
\end{array}$ & $\begin{array}{c}0.202 \\
(0.000 \\
\end{array}$ & $\begin{array}{c}0.211 \\
(0.000\end{array}$ & $\begin{array}{c}0.282 \\
(0.000 \\
\end{array}$ & $\begin{array}{c}0.273 \\
(0.000 \\
\end{array}$ & $\begin{array}{c}0.292 \\
(0.000\end{array}$ & $\begin{array}{r}0.305 \\
(0.000 \\
\end{array}$ \\
\hline Ind1 & $\begin{array}{l}-5.413 \\
(0.000\end{array}$ & $\begin{array}{l}-5.134 \\
(0.000\end{array}$ & $\begin{array}{l}-5.345 \\
(0.000\end{array}$ & & $\begin{array}{l}-4.355 \\
(0.000\end{array}$ & $\begin{array}{l}-3.586 \\
(0.000\end{array}$ & $\begin{array}{l}-4.120 \\
(0.000\end{array}$ & & $\begin{array}{l}-5.054 \\
(0.000\end{array}$ & $\begin{array}{l}-3.984 \\
(0.000\end{array}$ & $\begin{array}{l}-4.740 \\
(0.000\end{array}$ & \\
\hline Ind2 & $\begin{array}{r}-3.593 \\
(0.001 \\
\end{array}$ & $\begin{array}{l}-3.341 \\
(0.000 \\
\end{array}$ & $\begin{array}{r}-3.801 \\
(0.001 \\
\end{array}$ & & $\begin{array}{l}-2.058 \\
(0.000 \\
\end{array}$ & $\begin{array}{l}-0.708 \\
(0.011 \\
\end{array}$ & $\begin{array}{l}-1.922 \\
(0.000 \\
\end{array}$ & & $\begin{array}{l}-2.374 \\
(0.000 \\
\end{array}$ & $\begin{array}{l}-0.643 \\
(0.170 \\
\end{array}$ & $\begin{array}{l}-2.208 \\
(0.000 \\
\end{array}$ & \\
\hline $\mathrm{R}^{2}$ & 9.750 & 9.256 & 8.730 & 8.454 & 21.070 & 19.903 & 19.691 & 17.916 & 22.509 & 21.372 & 20.973 & 18.789 \\
\hline
\end{tabular}


Table 7: Panel Estimation: Firms with Low Default Probability-DCC Estimates

This table displays the results of the system GMM two-step estimation of a model with dynamic conditional stock-bond return correlations as dependent variables and the variables indicated in the left column as explanatory variables in a subsample of firms with normal levels of default probability. The sample was divided using the 75th percentile of the default probability of all firms. The values in parentheses are the $p$-values associated with Windmeijer (2005) corrected standard errors. The system of moment conditions is collapsed using two or more lags of the dependent variable. The explanatory variables are assumed to be strictly exogenous. The number of instruments is reported at the top of each column, the Arellano-Bond test for residual autocorrelation is reported toward the bottom for orders 1 and 2, and the Hansen and Sargan tests are in the bottom rows.

\begin{tabular}{|c|c|c|c|c|c|c|c|c|c|c|}
\hline \#Instruments & 97 & 97 & 98 & 97 & 96 & 97 & 96 & 97 & 96 & 97 \\
\hline $\mathrm{q}_{\mathrm{t}-1}$ & $\begin{array}{c}0.336 \\
(0.000)\end{array}$ & $\begin{array}{c}0.326 \\
(0.000)\end{array}$ & $\begin{array}{c}0.329 \\
(0.000)\end{array}$ & $\begin{array}{c}0.325 \\
(0.000)\end{array}$ & $\begin{array}{c}0.322 \\
(0.000)\end{array}$ & $\begin{array}{c}0.328 \\
(0.000)\end{array}$ & $\begin{array}{c}0.330 \\
(0.000)\end{array}$ & $\begin{array}{c}0.332 \\
(0.000)\end{array}$ & $\begin{array}{c}0.334 \\
(0.000)\end{array}$ & $\begin{array}{c}0.328 \\
(0.000)\end{array}$ \\
\hline$\sigma_{\mathrm{c}}$ & & $\begin{array}{l}-10.35 \\
(0.000)\end{array}$ & $\begin{array}{l}-9.943 \\
(0.000)\end{array}$ & $\begin{array}{l}-8.815 \\
(0.000)\end{array}$ & & & & $\begin{array}{l}-9.845 \\
(0.000)\end{array}$ & & $\begin{array}{l}-10.06 \\
(0.000)\end{array}$ \\
\hline Default & $\begin{array}{l}-3.435 \\
(0.003)\end{array}$ & & & & & $\begin{array}{l}-2.565 \\
(0.030)\end{array}$ & $\begin{array}{l}-0.597 \\
(0.360)\end{array}$ & $\begin{array}{c}0.456 \\
(0.532)\end{array}$ & $\begin{array}{l}-3.763 \\
(0.001)\end{array}$ & \\
\hline Term & & & $\begin{array}{l}-0.0915 \\
(0.879)\end{array}$ & & & & & & & $\begin{array}{l}-0.194 \\
(0.729)\end{array}$ \\
\hline VIX & & & & & $\begin{array}{l}-0.657 \\
(0.305)\end{array}$ & & & & & \\
\hline$\sigma^{\text {Id }}$ & $\begin{array}{c}0.789 \\
(0.001)\end{array}$ & $\begin{array}{c}0.514 \\
(0.002)\end{array}$ & $\begin{array}{c}0.508 \\
(0.002)\end{array}$ & & & $\begin{array}{c}0.549 \\
(0.019)\end{array}$ & & & $\begin{array}{c}0.758 \\
(0.001)\end{array}$ & $\begin{array}{c}0.480 \\
(0.003)\end{array}$ \\
\hline Lev & & & & $\begin{array}{c}0.661 \\
(0.018)\end{array}$ & $\begin{array}{c}0.773 \\
(0.006)\end{array}$ & $\begin{array}{c}0.683 \\
(0.013)\end{array}$ & & & & \\
\hline$\beta^{\mathrm{UN}}$ & $\begin{array}{l}-0.780 \\
(0.007)\end{array}$ & $\begin{array}{l}-0.669 \\
(0.020)\end{array}$ & $\begin{array}{l}-0.651 \\
(0.025)\end{array}$ & $\begin{array}{l}-0.463 \\
(0.103)\end{array}$ & & & $\begin{array}{l}-0.582 \\
(0.043)\end{array}$ & $\begin{array}{l}-0.584 \\
(0.038)\end{array}$ & $\begin{array}{c}-0.808 \\
(0.006)\end{array}$ & $\begin{array}{l}-0.662 \\
(0.022)\end{array}$ \\
\hline Def. Prob & $\begin{array}{l}-1.195 \\
(0.198) \\
\end{array}$ & $\begin{array}{l}-0.625 \\
(0.466)\end{array}$ & $\begin{array}{l}-0.646 \\
(0.481) \\
\end{array}$ & $\begin{array}{l}-0.496 \\
(0.557) \\
\end{array}$ & $\begin{array}{l}-2.237 \\
(0.018) \\
\end{array}$ & $\begin{array}{l}-2.596 \\
(0.007)\end{array}$ & $\begin{array}{l}-0.305 \\
(0.749)\end{array}$ & $\begin{array}{c}0.743 \\
(0.414)\end{array}$ & & \\
\hline Time & $\begin{array}{c}0.103 \\
(0.057)\end{array}$ & $\begin{array}{l}0.0980 \\
(0.069)\end{array}$ & $\begin{array}{l}0.0942 \\
(0.082)\end{array}$ & $\begin{array}{l}0.0941 \\
(0.076)\end{array}$ & $\begin{array}{c}0.102 \\
(0.055)\end{array}$ & $\begin{array}{l}0.0983 \\
(0.065)\end{array}$ & $\begin{array}{c}0.111 \\
(0.040)\end{array}$ & $\begin{array}{c}0.103 \\
(0.055)\end{array}$ & $\begin{array}{c}0.101 \\
(0.060)\end{array}$ & $\begin{array}{l}0.0936 \\
(0.083)\end{array}$ \\
\hline Ind1 & $\begin{array}{l}-3.297 \\
(0.010)\end{array}$ & $\begin{array}{l}-3.611 \\
(0.007)\end{array}$ & $\begin{array}{l}-3.483 \\
(0.010)\end{array}$ & $\begin{array}{l}-3.714 \\
(0.005)\end{array}$ & $\begin{array}{l}-3.781 \\
(0.003)\end{array}$ & $\begin{array}{l}-3.480 \\
(0.007)\end{array}$ & $\begin{array}{l}-3.642 \\
(0.004)\end{array}$ & $\begin{array}{l}-3.710 \\
(0.005)\end{array}$ & $\begin{array}{l}-3.226 \\
(0.011)\end{array}$ & $\begin{array}{l}-3.466 \\
(0.010)\end{array}$ \\
\hline Ind2 & $\begin{array}{l}-1.151 \\
(0.375)\end{array}$ & $\begin{array}{l}-1.476 \\
(0.270)\end{array}$ & $\begin{array}{l}-1.327 \\
(0.326)\end{array}$ & $\begin{array}{l}-2.219 \\
(0.105)\end{array}$ & $\begin{array}{l}-2.175 \\
(0.106)\end{array}$ & $\begin{array}{l}-1.799 \\
(0.179)\end{array}$ & $\begin{array}{l}-1.580 \\
(0.224)\end{array}$ & $\begin{array}{l}-1.728 \\
(0.196)\end{array}$ & $\begin{array}{l}-1.092 \\
(0.398)\end{array}$ & $\begin{array}{l}-1.332 \\
(0.327)\end{array}$ \\
\hline Constant & $\begin{array}{c}2.486 \\
(0.051) \\
\end{array}$ & $\begin{array}{c}4.206 \\
(0.002)\end{array}$ & $\begin{array}{c}4.021 \\
(0.003) \\
\end{array}$ & $\begin{array}{c}4.332 \\
(0.002) \\
\end{array}$ & $\begin{array}{c}2.481 \\
(0.054) \\
\end{array}$ & $\begin{array}{c}2.089 \\
(0.107)\end{array}$ & $\begin{array}{c}2.855 \\
(0.024)\end{array}$ & $\begin{array}{c}4.574 \\
(0.001)\end{array}$ & $\begin{array}{c}2.505 \\
(0.050)\end{array}$ & $\begin{array}{c}4.056 \\
(0.003)\end{array}$ \\
\hline $\begin{array}{l}\text { Are-Bond } \\
\text { AR(1) Test }\end{array}$ & $\begin{array}{l}-7.340 \\
(0.000)\end{array}$ & $\begin{array}{l}-7.361 \\
(0.000)\end{array}$ & $\begin{array}{l}-7.439 \\
(0.000)\end{array}$ & $\begin{array}{l}-7.329 \\
(0.000)\end{array}$ & $\begin{array}{l}-7.295 \\
(0.000)\end{array}$ & $\begin{array}{l}-7.342 \\
(0.000)\end{array}$ & $\begin{array}{l}-7.356 \\
(0.000)\end{array}$ & $\begin{array}{l}-7.374 \\
(0.000)\end{array}$ & $\begin{array}{l}-7.335 \\
(0.000)\end{array}$ & $\begin{array}{l}-7.449 \\
(0.000)\end{array}$ \\
\hline $\begin{array}{l}\text { Are-Bond } \\
\text { AR(2) Test }\end{array}$ & $\begin{array}{l}-1.888 \\
(0.059)\end{array}$ & $\begin{array}{l}-2.002 \\
(0.045)\end{array}$ & $\begin{array}{l}-1.977 \\
(0.048)\end{array}$ & $\begin{array}{l}-2.022 \\
(0.043)\end{array}$ & $\begin{array}{l}-2.032 \\
(0.042)\end{array}$ & $\begin{array}{l}-1.956 \\
(0.050)\end{array}$ & $\begin{array}{l}-1.969 \\
(0.049)\end{array}$ & $\begin{array}{l}-1.963 \\
(0.049)\end{array}$ & $\begin{array}{l}-1.900 \\
(0.057)\end{array}$ & $\begin{array}{l}-1.987 \\
(0.047)\end{array}$ \\
\hline $\begin{array}{l}\text { Are-Bond } \\
\text { AR(3) Test }\end{array}$ & $\begin{array}{c}1.476 \\
(0.140) \\
\end{array}$ & $\begin{array}{c}1.479 \\
(0.139) \\
\end{array}$ & $\begin{array}{r}1.497 \\
(0.134) \\
\end{array}$ & $\begin{array}{r}1.507 \\
(0.132) \\
\end{array}$ & $\begin{array}{c}1.424 \\
(0.154) \\
\end{array}$ & $\begin{array}{c}1.425 \\
(0.154) \\
\end{array}$ & $\begin{array}{c}1.528 \\
(0.126) \\
\end{array}$ & $\begin{array}{r}1.565 \\
(0.118) \\
\end{array}$ & $\begin{array}{c}1.489 \\
(0.136) \\
\end{array}$ & $\begin{array}{c}1.503 \\
(0.133) \\
\end{array}$ \\
\hline Sargan Test & $\begin{array}{c}87.66 \\
(0.490)\end{array}$ & $\begin{array}{c}83.01 \\
(0.630)\end{array}$ & $\begin{array}{c}83.22 \\
(0.624)\end{array}$ & $\begin{array}{c}89.70 \\
(0.430)\end{array}$ & $\begin{array}{c}89.49 \\
(0.436)\end{array}$ & $\begin{array}{c}88.07 \\
(0.478)\end{array}$ & $\begin{array}{c}90.54 \\
(0.405)\end{array}$ & $\begin{array}{c}90.68 \\
(0.401)\end{array}$ & $\begin{array}{c}87.23 \\
(0.503)\end{array}$ & $\begin{array}{c}82.97 \\
(0.632)\end{array}$ \\
\hline Hansen Test & $\begin{array}{c}83.51 \\
(0.616)\end{array}$ & $\begin{array}{c}81.12 \\
(0.685)\end{array}$ & $\begin{array}{c}81.87 \\
(0.664)\end{array}$ & $\begin{array}{c}81.08 \\
(0.686)\end{array}$ & $\begin{array}{c}79.36 \\
(0.733)\end{array}$ & $\begin{array}{c}81.42 \\
(0.677)\end{array}$ & $\begin{array}{c}79.88 \\
(0.719)\end{array}$ & $\begin{array}{c}80.83 \\
(0.693)\end{array}$ & $\begin{array}{c}83.23 \\
(0.624)\end{array}$ & $\begin{array}{c}81.72 \\
(0.668)\end{array}$ \\
\hline
\end{tabular}


Table 8: Panel Estimation: Firms with High Default Probability-DCC Estimates

The table displays the results of the system GMM two-step estimation of a model with dynamic conditional stock-bond return correlations as dependent variables and the variables indicated in the left column as explanatory variables in a subsample of firms with a high probability of default. The sample was divided using the 75th percentile of the default probability of all firms. The values in parentheses are the $p$-values associated with Windmeijer (2005) corrected standard errors. The system of moment conditions is collapsed using two or more lags of the dependent variable. The explanatory variables are assumed to be strictly exogenous. The number of instruments is reported at the top of each column, the Arellano-Bond test for residual autocorrelation is reported toward the bottom for orders 1 and 2, and the Hansen and Sargan tests are in the bottom rows.

\begin{tabular}{|c|c|c|c|c|c|c|c|c|c|c|}
\hline \#Instruments & 97 & 97 & 98 & 97 & 96 & 97 & 96 & 97 & 97 & 96 \\
\hline $\mathrm{q}_{\mathrm{t}-1}$ & $\begin{array}{c}0.598 \\
(0.000)\end{array}$ & $\begin{array}{c}0.600 \\
(0.000)\end{array}$ & $\begin{array}{c}0.598 \\
(0.000)\end{array}$ & $\begin{array}{c}0.616 \\
(0.000)\end{array}$ & $\begin{array}{c}0.572 \\
(0.000)\end{array}$ & $\begin{array}{c}0.581 \\
(0.000)\end{array}$ & $\begin{array}{c}0.614 \\
(0.000)\end{array}$ & $\begin{array}{c}0.612 \\
(0.000)\end{array}$ & $\begin{array}{c}0.602 \\
(0.000)\end{array}$ & $\begin{array}{c}0.598 \\
(0.000)\end{array}$ \\
\hline$\sigma_{\mathrm{c}}$ & & $\begin{array}{l}-5.060 \\
(0.095)\end{array}$ & $\begin{array}{l}-5.135 \\
(0.096)\end{array}$ & $\begin{array}{l}-3.529 \\
(0.176)\end{array}$ & & & & $\begin{array}{l}-5.447 \\
(0.071)\end{array}$ & & $\begin{array}{l}-10.02 \\
(0.082)\end{array}$ \\
\hline Default & $\begin{array}{l}-1.410 \\
(0.222)\end{array}$ & & & & & $\begin{array}{l}-0.788 \\
(0.462)\end{array}$ & $\begin{array}{c}0.583 \\
(0.384)\end{array}$ & $\begin{array}{c}1.353 \\
(0.084)\end{array}$ & $\begin{array}{l}-1.096 \\
(0.319)\end{array}$ & \\
\hline Term & & & $\begin{array}{l}0.0107 \\
(0.989)\end{array}$ & & & & & & & $\begin{array}{c}2.073 \\
(0.381)\end{array}$ \\
\hline VIX & & & & & $\begin{array}{c}1.734 \\
(0.009)\end{array}$ & & & & & \\
\hline$\sigma^{\mathrm{Id}}$ & $\begin{array}{c}0.195 \\
(0.026)\end{array}$ & $\begin{array}{c}0.151 \\
(0.012) \\
\end{array}$ & $\begin{array}{c}0.153 \\
(0.011) \\
\end{array}$ & & & $\begin{array}{c}0.103 \\
(0.201)\end{array}$ & & & $\begin{array}{c}0.157 \\
(0.057) \\
\end{array}$ & $\begin{array}{c}0.107 \\
(0.091)\end{array}$ \\
\hline Lev & & & & $\begin{array}{l}0.0617 \\
(0.025)\end{array}$ & $\begin{array}{l}0.0911 \\
(0.009)\end{array}$ & $\begin{array}{l}0.0817 \\
(0.016)\end{array}$ & & & & \\
\hline$\beta^{\mathrm{UN}}$ & $\begin{array}{l}-1.070 \\
(0.008)\end{array}$ & $\begin{array}{l}-1.010 \\
(0.012) \\
\end{array}$ & $\begin{array}{l}-1.029 \\
(0.012)\end{array}$ & $\begin{array}{l}-0.737 \\
(0.034) \\
\end{array}$ & & & $\begin{array}{l}-1.090 \\
(0.007)\end{array}$ & $\begin{array}{l}-1.022 \\
(0.011)\end{array}$ & $\begin{array}{l}-1.196 \\
(0.003)\end{array}$ & $\begin{array}{l}-1.070 \\
(0.008)\end{array}$ \\
\hline Def. Prob & $\begin{array}{l}-0.026 \\
(0.256)\end{array}$ & $\begin{array}{l}-0.024 \\
(0.303)\end{array}$ & $\begin{array}{c}-0.024 \\
(0.295)\end{array}$ & $\begin{array}{l}-0.025 \\
(0.312)\end{array}$ & $\begin{array}{l}-0.063 \\
(0.022)\end{array}$ & $\begin{array}{l}-0.059 \\
(0.034)\end{array}$ & $\begin{array}{l}-0.008 \\
(0.722)\end{array}$ & $\begin{array}{l}-0.008 \\
(0.726)\end{array}$ & & \\
\hline Time & $\begin{array}{l}0.0102 \\
(0.844)\end{array}$ & $\begin{array}{l}0.0006 \\
(0.990) \\
\end{array}$ & $\begin{array}{c}0.004 \\
(0.937)\end{array}$ & $\begin{array}{c}0.015 \\
(0.749)\end{array}$ & $\begin{array}{l}0.0006 \\
(0.990)\end{array}$ & $\begin{array}{l}0.0015 \\
(0.976)\end{array}$ & $\begin{array}{c}0.008 \\
(0.859)\end{array}$ & $\begin{array}{c}0.004 \\
(0.926)\end{array}$ & $\begin{array}{c}0.022 \\
(0.658)\end{array}$ & $\begin{array}{c}0.002 \\
(0.973)\end{array}$ \\
\hline Ind1 & $\begin{array}{l}-1.709 \\
(0.001)\end{array}$ & $\begin{array}{l}-1.668 \\
(0.001)\end{array}$ & $\begin{array}{l}-1.695 \\
(0.001)\end{array}$ & $\begin{array}{l}-1.593 \\
(0.002)\end{array}$ & $\begin{array}{l}-1.988 \\
(0.000)\end{array}$ & $\begin{array}{l}-1.981 \\
(0.000)\end{array}$ & $\begin{array}{l}-1.549 \\
(0.002)\end{array}$ & $\begin{array}{l}-1.556 \\
(0.002)\end{array}$ & $\begin{array}{l}-1.761 \\
(0.002)\end{array}$ & $\begin{array}{l}-1.725 \\
(0.001)\end{array}$ \\
\hline Ind2 & $\begin{array}{l}-0.928 \\
(0.044) \\
\end{array}$ & $\begin{array}{l}-0.864 \\
(0.049) \\
\end{array}$ & $\begin{array}{c}-0.888 \\
(0.047)\end{array}$ & $\begin{array}{l}-0.943 \\
(0.030)\end{array}$ & $\begin{array}{l}-1.004 \\
(0.021) \\
\end{array}$ & $\begin{array}{l}-0.952 \\
(0.029) \\
\end{array}$ & $\begin{array}{l}-0.777 \\
(0.071)\end{array}$ & $\begin{array}{l}-0.749 \\
(0.071)\end{array}$ & $\begin{array}{l}-0.943 \\
(0.047)\end{array}$ & $\begin{array}{l}-0.975 \\
(0.029) \\
\end{array}$ \\
\hline Constant & $\begin{array}{c}2.767 \\
(0.000) \\
\end{array}$ & $\begin{array}{c}3.417 \\
(0.000) \\
\end{array}$ & $\begin{array}{c}3.442 \\
(0.000) \\
\end{array}$ & $\begin{array}{c}3.018 \\
(0.000) \\
\end{array}$ & $\begin{array}{c}1.715 \\
(0.001)\end{array}$ & $\begin{array}{c}2.030 \\
(0.000)\end{array}$ & $\begin{array}{c}2.518 \\
(0.000)\end{array}$ & $\begin{array}{c}3.330 \\
(0.000)\end{array}$ & $\begin{array}{c}2.777 \\
(0.000)\end{array}$ & $\begin{array}{c}4.234 \\
(0.000)\end{array}$ \\
\hline $\begin{array}{l}\text { Are-Bond } \\
\text { AR(1) Test }\end{array}$ & $\begin{array}{l}-6.213 \\
(0.000) \\
\end{array}$ & $\begin{array}{l}-6.267 \\
(0.000) \\
\end{array}$ & $\begin{array}{l}-6.247 \\
(0.000) \\
\end{array}$ & $\begin{array}{l}-6.297 \\
(0.000) \\
\end{array}$ & $\begin{array}{l}-6.236 \\
(0.000) \\
\end{array}$ & $\begin{array}{l}-6.181 \\
(0.000) \\
\end{array}$ & $\begin{array}{l}-6.332 \\
(0.000) \\
\end{array}$ & $\begin{array}{l}-6.343 \\
(0.000) \\
\end{array}$ & $\begin{array}{l}-6.219 \\
(0.000) \\
\end{array}$ & $\begin{array}{l}-6.249 \\
(0.000) \\
\end{array}$ \\
\hline $\begin{array}{l}\text { Are-Bond } \\
\text { AR(2) Test }\end{array}$ & $\begin{array}{l}-0.612 \\
(0.541) \\
\end{array}$ & $\begin{array}{l}-0.599 \\
(0.549) \\
\end{array}$ & $\begin{array}{l}-0.608 \\
(0.543)\end{array}$ & $\begin{array}{l}-0.505 \\
(0.614)\end{array}$ & $\begin{array}{l}-0.585 \\
(0.559) \\
\end{array}$ & $\begin{array}{l}-0.591 \\
(0.554) \\
\end{array}$ & $\begin{array}{l}-0.517 \\
(0.605)\end{array}$ & $\begin{array}{l}-0.522 \\
(0.602)\end{array}$ & $\begin{array}{l}-0.594 \\
(0.552)\end{array}$ & $\begin{array}{l}-0.601 \\
(0.548) \\
\end{array}$ \\
\hline Sargan Test & $\begin{array}{c}120.3 \\
(0.013)\end{array}$ & $\begin{array}{c}121.2 \\
(0.011)\end{array}$ & $\begin{array}{c}120.9 \\
(0.012)\end{array}$ & $\begin{array}{c}120.2 \\
(0.013)\end{array}$ & $\begin{array}{c}116.8 \\
(0.022)\end{array}$ & $\begin{array}{c}117.4 \\
(0.020)\end{array}$ & $\begin{array}{c}119.7 \\
(0.014)\end{array}$ & $\begin{array}{c}120.3 \\
(0.013)\end{array}$ & $\begin{array}{c}120.0 \\
(0.016)\end{array}$ & $\begin{array}{c}119.7 \\
(0.013)\end{array}$ \\
\hline Hansen Test & $\begin{array}{c}85.55 \\
(0.554)\end{array}$ & $\begin{array}{c}86.58 \\
(0.523)\end{array}$ & $\begin{array}{c}86.98 \\
(0.511)\end{array}$ & $\begin{array}{c}86.51 \\
(0.525)\end{array}$ & $\begin{array}{c}84.32 \\
(0.591)\end{array}$ & $\begin{array}{c}84.31 \\
(0.592)\end{array}$ & $\begin{array}{c}87.28 \\
(0.502)\end{array}$ & $\begin{array}{c}87.51 \\
(0.495)\end{array}$ & $\begin{array}{c}87.36 \\
(0.529)\end{array}$ & $\begin{array}{c}86.75 \\
(0.487)\end{array}$ \\
\hline
\end{tabular}


Table 9: Panel Estimation-Adjustment Speed

The table displays the results of the following speed of adjustment regression model $L e v_{j t}=\left(1-\lambda_{0}\right) L e v_{j t-h}-\lambda_{1} q_{i j t} L e v_{j t-h}+\sum_{k=1}^{K} \gamma_{k} X_{k j t-h}-\sum_{k=1}^{K} \delta_{k} q_{i j t} X_{k j t-h}+\varepsilon_{j t}$,

where Lev is the leverage ratio of the firm $j, q$ is the correlation between stock and bonds issued by the firm, and $X$ is a set of variables representing firm characteristics to determine the long run target leverage. These variables include the market-to-book ratio (MTB), the return on earnings (ROA), the effective tax rate (TAX), the logarithm of the total assets (Size), the interest coverage ratio (IC), the percentage of intangible over total assets (Intang) and the average leverage ratio within all firms in the industry (LevInd). All models are estimated with fixed effects and the inclusion of year dummies is indicated in the bottom row. The values in parentheses are the $t$-statistics.

\begin{tabular}{|c|c|c|c|c|c|c|c|c|c|c|}
\hline \# Instruments & (1) & (2) & (3) & (4) & (5) & (6) & (7) & (8) & (9) & (10) \\
\hline$\overline{\operatorname{Lev}_{\mathrm{t}-4}}$ & & & $\begin{array}{r}0.720 \\
(14.06)\end{array}$ & $\begin{array}{r}0.669 \\
(11.12)\end{array}$ & $\begin{array}{r}0.659 \\
(12.01)\end{array}$ & $\begin{array}{r}0.668 \\
(11.06)\end{array}$ & $\begin{array}{r}0.657 \\
(11.98)\end{array}$ & $\begin{array}{r}0.664 \\
(10.98)\end{array}$ & $\begin{array}{r}0.668 \\
(11.11)\end{array}$ & $\begin{array}{r}0.647 \\
(10.62)\end{array}$ \\
\hline $\mathrm{MTB}_{\mathrm{t}-4}$ & $\begin{array}{l}0.099 \\
(1.85)\end{array}$ & $\begin{array}{l}-0.265 \\
(-2.82)\end{array}$ & $\begin{array}{l}-0.340 \\
(-3.59)\end{array}$ & $\begin{array}{l}-0.426 \\
(-3.92)\end{array}$ & $\begin{array}{l}-0.217 \\
(-2.77)\end{array}$ & $\begin{array}{l}-0.391 \\
(-3.64)\end{array}$ & $\begin{array}{l}-0.189 \\
(-2.44)\end{array}$ & $\begin{array}{l}-0.629 \\
(-6.02)\end{array}$ & $\begin{array}{l}-0.402 \\
(-3.72)\end{array}$ & $\begin{array}{l}-0.248 \\
(-2.63)\end{array}$ \\
\hline $\mathrm{ROA}_{\mathrm{t}-4}$ & $\begin{array}{l}-9.078 \\
(-3.86)\end{array}$ & $\begin{array}{l}-6.279 \\
(-3.36)\end{array}$ & $\begin{array}{l}0.928 \\
(0.88)\end{array}$ & $\begin{array}{l}4.159 \\
(2.55)\end{array}$ & $\begin{array}{l}4.222 \\
(2.66)\end{array}$ & & $\begin{array}{l}4.321 \\
(2.67)\end{array}$ & $\begin{array}{l}4.125 \\
(2.68)\end{array}$ & $\begin{array}{l}4.252 \\
(2.56)\end{array}$ & $\begin{array}{l}4.499 \\
(2.66)\end{array}$ \\
\hline $\mathrm{TAX}_{\mathrm{t}-4}$ & $\begin{array}{l}-1.953 \\
(-0.40)\end{array}$ & $\begin{array}{l}-1.752 \\
(-0.37)\end{array}$ & $\begin{array}{l}22.85 \\
(7.42)\end{array}$ & & $\begin{array}{l}3.124 \\
(1.51)\end{array}$ & & $\begin{array}{l}3.050 \\
(1.48)\end{array}$ & & & \\
\hline$\overline{\text { Size }_{\mathrm{t}-4}}$ & $\begin{array}{l}1.081 \\
(7.26)\end{array}$ & $\begin{array}{l}1.178 \\
(6.34)\end{array}$ & $\begin{array}{l}1.350 \\
(6.09)\end{array}$ & $\begin{array}{l}1.176 \\
(3.95)\end{array}$ & $\begin{array}{l}1.489 \\
(5.11)\end{array}$ & $\begin{array}{l}1.177 \\
(3.95)\end{array}$ & $\begin{array}{l}1.366 \\
(4.78)\end{array}$ & & $\begin{array}{r}1.063 \\
(3.48)\end{array}$ & $\begin{array}{l}1.269 \\
(4.58)\end{array}$ \\
\hline $\mathrm{IC}_{\mathrm{t}-4}$ & $\begin{array}{l}-2.7 \mathrm{E}-5 \\
(-0.34)\end{array}$ & $\begin{array}{l}-6.5 \mathrm{E}-4 \\
(-3.43)\end{array}$ & $\begin{array}{l}-4.6 \mathrm{E}-4 \\
(-3.16)\end{array}$ & $\begin{array}{l}0.014 \\
(3.10)\end{array}$ & & $\begin{array}{l}0.015 \\
(3.21)\end{array}$ & & $\begin{array}{l}0.013 \\
(2.99)\end{array}$ & $\begin{array}{l}0.015 \\
(3.14)\end{array}$ & \\
\hline Intang $_{\mathrm{t}-4}$ & $\begin{array}{l}0.249 \\
(1.00)\end{array}$ & $\begin{array}{l}0.025 \\
(0.07)\end{array}$ & $\begin{array}{l}-1.083 \\
(-2.98)\end{array}$ & $\begin{array}{l}-0.838 \\
(-1.69)\end{array}$ & $\begin{array}{l}-0.915 \\
(-1.76)\end{array}$ & $\begin{array}{l}-0.890 \\
(-1.76)\end{array}$ & & $\begin{array}{l}-0.307 \\
(-0.89)\end{array}$ & & \\
\hline LevInd $_{t-4}$ & $\begin{array}{l}1.8 \mathrm{E}-5 \\
(0.88)\end{array}$ & $\begin{array}{l}-2.1 \mathrm{E}-4 \\
(-8.52)\end{array}$ & $\begin{array}{r}-4.2 \mathrm{E}-4 \\
(-10.15)\end{array}$ & $\begin{array}{l}-3.5 \mathrm{E}-4 \\
(-7.51)\end{array}$ & $\begin{array}{l}-2.8 \mathrm{E}-4 \\
(-6.88)\end{array}$ & $\begin{array}{l}-3.6 \mathrm{E}-4 \\
(-7.54)\end{array}$ & $\begin{array}{l}-2.8 \mathrm{E}-4 \\
(-6.90)\end{array}$ & $\begin{array}{l}-3.6 \mathrm{E}-4 \\
(-7.50)\end{array}$ & $\begin{array}{l}-3.5 \mathrm{E}-4 \\
(-7.52)\end{array}$ & $\begin{array}{l}-2.9 \mathrm{E}-4 \\
(-6.86)\end{array}$ \\
\hline $\mathrm{q}_{\mathrm{t}}{ }^{*} \operatorname{Lev}_{\mathrm{t}-4}$ & & & & $\begin{array}{l}-3.568 \\
(-3.36)\end{array}$ & $\begin{array}{l}-2.329 \\
(-2.41)\end{array}$ & $\begin{array}{l}-3.571 \\
(-3.35)\end{array}$ & $\begin{array}{l}-2.352 \\
(-2.42)\end{array}$ & $\begin{array}{l}-3.712 \\
(-3.49)\end{array}$ & $\begin{array}{l}-3.571 \\
(-3.37)\end{array}$ & $\begin{array}{l}-3.610 \\
(-3.37)\end{array}$ \\
\hline $\mathrm{q}_{\mathrm{t}} * \mathrm{MTB}_{\mathrm{t}-4}$ & & & & $\begin{array}{l}3.167 \\
(1.91)\end{array}$ & $\begin{array}{l}1.470 \\
(1.03)\end{array}$ & $\begin{array}{l}3.212 \\
(1.85)\end{array}$ & $\begin{array}{l}1.837 \\
(1.28)\end{array}$ & $\begin{array}{r}0.0711 \\
(0.05)\end{array}$ & $\begin{array}{l}3.449 \\
(2.05)\end{array}$ & $\begin{array}{l}3.166 \\
(2.13)\end{array}$ \\
\hline $\mathrm{q}_{\mathrm{t}} * \mathrm{ROA}_{\mathrm{t}-4}$ & & & & $\begin{array}{l}3.926 \\
(0.11)\end{array}$ & $\begin{array}{l}-21.18 \\
(-0.71)\end{array}$ & & $\begin{array}{l}-23.15 \\
(-0.75)\end{array}$ & $\begin{array}{l}9.689 \\
(0.27)\end{array}$ & $\begin{array}{l}2.289 \\
(0.07)\end{array}$ & $\begin{array}{l}1.318 \\
(0.04)\end{array}$ \\
\hline $\mathrm{q}_{\mathrm{t}}$ *TAX $\mathrm{TA}_{\mathrm{t}-4}$ & & & & & $\begin{array}{l}152.1 \\
(3.16)\end{array}$ & & $\begin{array}{l}150.0 \\
(3.14)\end{array}$ & & & \\
\hline $\mathrm{q}_{\mathrm{t}} * \operatorname{Size}_{\mathrm{t}-4}$ & & & & $\begin{array}{r}18.770 \\
(2.72)\end{array}$ & $\begin{array}{l}14.97 \\
(2.28)\end{array}$ & $\begin{array}{l}19.13 \\
(2.71)\end{array}$ & $\begin{array}{l}12.79 \\
(1.71)\end{array}$ & & $\begin{array}{l}17.59 \\
(2.35)\end{array}$ & $\begin{array}{l}16.85 \\
(2.59)\end{array}$ \\
\hline $\mathrm{q}_{\mathrm{t}} * \mathrm{IC}_{\mathrm{t}-4}$ & & & & $\begin{array}{l}0.288 \\
(3.57)\end{array}$ & & $\begin{array}{l}0.293 \\
(3.54)\end{array}$ & & $\begin{array}{l}0.243 \\
(3.20)\end{array}$ & $\begin{array}{l}0.288 \\
(3.58)\end{array}$ & \\
\hline $\mathrm{q}_{\mathrm{t}} *$ Intang $_{\mathrm{t}-4}$ & & & & $\begin{array}{l}-11.15 \\
(-0.80)\end{array}$ & $\begin{array}{l}-21.35 \\
(-1.28)\end{array}$ & $\begin{array}{l}-10.06 \\
(-0.71)\end{array}$ & & $\begin{array}{l}3.532 \\
(0.65)\end{array}$ & & \\
\hline $\mathrm{q}_{\mathrm{t}} * \operatorname{LevInd}_{\mathrm{t}-4}$ & & & & $\begin{array}{l}1.3 \mathrm{E}-4 \\
(0.32)\end{array}$ & $\begin{array}{l}-7.9 \mathrm{E}-5 \\
(-0.23)\end{array}$ & $\begin{array}{l}8.8 \mathrm{E}-5 \\
(0.21)\end{array}$ & $\begin{array}{l}-1.7 \mathrm{E}-4 \\
(-0.50)\end{array}$ & $\begin{array}{l}3.3 \mathrm{E}-4 \\
(0.83)\end{array}$ & $\begin{array}{l}6.7 \mathrm{E}-5 \\
(0.16)\end{array}$ & $\begin{array}{l}1.0 \mathrm{E}-4 \\
(0.30)\end{array}$ \\
\hline Constant & $\begin{array}{r}0.545 \\
(33.51)\end{array}$ & $\begin{array}{l}0.731 \\
(9.48)\end{array}$ & $\begin{array}{l}-0.483 \\
(-3.55)\end{array}$ & $\begin{array}{r}2.387 \\
(10.56)\end{array}$ & $\begin{array}{r}2.163 \\
(11.30)\end{array}$ & $\begin{array}{r}2.386 \\
(10.55)\end{array}$ & $\begin{array}{r}2.173 \\
(11.27)\end{array}$ & $\begin{array}{r}2.513 \\
(10.56)\end{array}$ & $\begin{array}{r}2.394 \\
(10.55)\end{array}$ & $\begin{array}{r}2.177 \\
(11.13)\end{array}$ \\
\hline $\begin{array}{c}\text { Year Dummies } \\
\mathrm{R}^{2}\end{array}$ & $\begin{array}{r}\text { No } \\
0.37\end{array}$ & $\begin{array}{r}\text { Yes } \\
4.6\end{array}$ & $\begin{array}{l}\text { Yes } \\
16.3\end{array}$ & $\begin{array}{l}\text { Yes } \\
14.6\end{array}$ & $\begin{array}{l}\text { Yes } \\
14.6\end{array}$ & $\begin{array}{l}\text { Yes } \\
14.6\end{array}$ & $\begin{array}{l}\text { Yes } \\
14.6\end{array}$ & $\begin{array}{l}\text { Yes } \\
14.4\end{array}$ & $\begin{array}{l}\text { Yes } \\
14.6\end{array}$ & $\begin{array}{l}\text { Yes } \\
13.7\end{array}$ \\
\hline
\end{tabular}


Figure 1: Time Series of Dynamic Correlations, Comparing a Three-Month Rolling Window Sample Correlation and the DCC Method

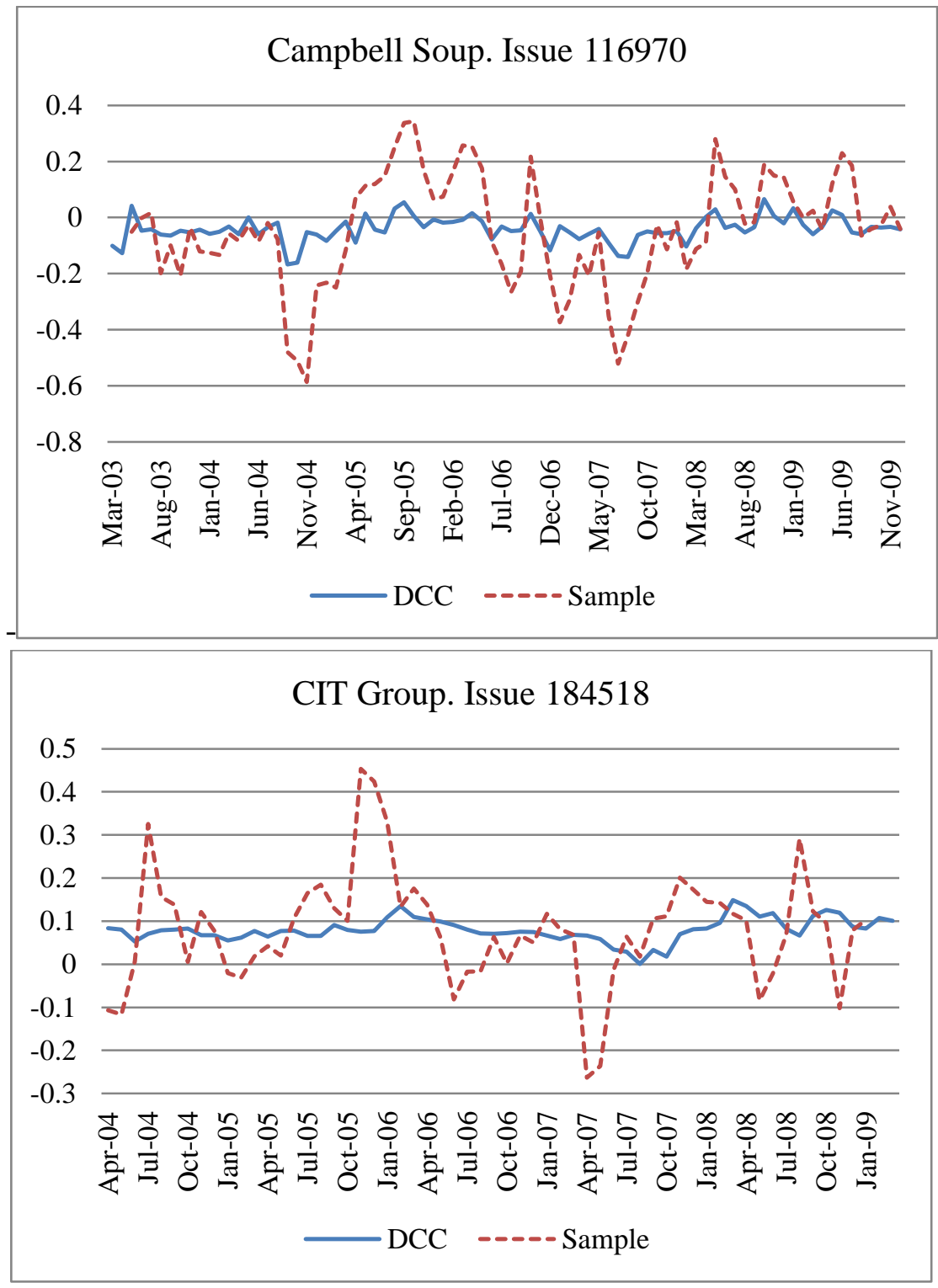


Figure 2: Time Series of the Standard DCC Estimation and the Correspondent Estimation Adjusted for Non-Trading Days (DCCD)



